Pamiętnik Literacki 2012, 1, s. 5-30
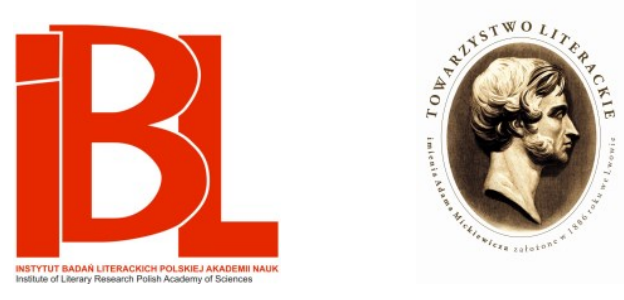

„Pszenica i kąkol”

Interteksty biblijne w „Lalce” Bolesława

Prusa

Cezary Zalewski 


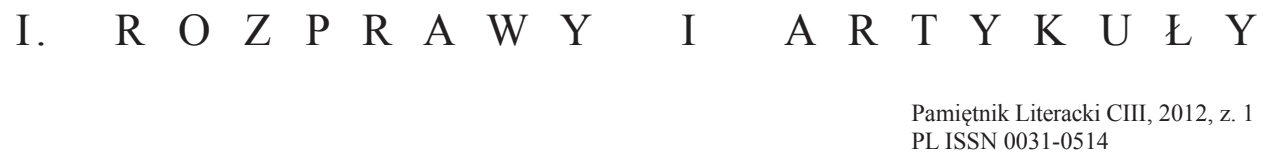

CEZARY ZALEWSKI

(Uniwersytet Jagielloński, Kraków)

\author{
„PSZENICA I KĄKOL” \\ INTERTEKSTY BIBLIJNE W „LALCE” BOLESŁAWA PRUSA
}

Pamięci Profesora Stanistawa Fity

Badacze zajmujący się intertekstualnością Lalki Bolesława Prusa zgodnie przyznają, iż w tej powieści spośród ogromu zapożyczeń z różnych utworów najwięcej ma źródło w Biblii ${ }^{1}$. Wszelako paradoksalny status tego konsensusu polega na tym, że zakłada on zarówno duży zakres występowania danego zjawiska, jak też jego minimalną funkcjonalizację. Jeśli bowiem dociekania nie poprzestają na zwykłym katalogu owych przywołań, który rejestruje stopień ich dokładności, to najczęściej prowadzą do takiego wniosku:

Nawiązania i aluzje [biblijne] nie stanowią celu samego w sobie, ich użycie uzasadnione jest każdorazowo względami konstrukcyjnymi i znaczeniowymi, podziwiać trzeba kunszt, z jakim pisarz włącza je do budowy stylistycznej powieści ${ }^{2}$.

Dopóki jednak twierdzenie takie nie będzie poparte odpowiednimi analizami, dopóty pozostaje wyłącznie hipotezą, której w sposób zadowalający nie udowadnia - oczywiste skądinąd - przekonanie dotyczące charakteryzowania bohaterów za pomocą tego typu odwołań.

Punktem wyjścia takich analiz jest technika wprowadzania zapożyczeń biblijnych, która nie ogranicza się do dwóch metod (cytaty i kryptocytaty). Ich pełnej prezentacji należałoby dokonać opierając się na klasyfikacji zaproponowanej przez Włodzimierza Boleckiego, który wyróżnił trzy sposoby włączania oraz wykorzystywania tzw. cytatu empirycznego. Pierwszy polega jedynie na umieszczeniu odpowiednio wyodrębnionego fragmentu, który nie wymaga żadnego komentarza; druga procedura natomiast koncentruje się wokół samego aktu cytowania, przy czym jego składnikiem „wcale nie musi być cytat”:

1 Zob. A. M a r t u s z e w s k a, ,Lalka” i niektóre problemy intertekstualności. W zb.: „Lalka” i inne. Studia w stulecie polskiej powieści realistycznej. Red. J. Bachórz, M. Głowiński. Warszawa 1992, s. 65. - K. To k a r zó w n a, Inspiracje i motywy biblijne w twórczości Bolesława Prusa. W zb.: Problematyka religijna w literaturze pozytywizmu i Młodej Polski. Red. S. Fita. Lublin 1993. - M. S z p i 1 a r e w i c z, Oblicza intertekstualności „,Lalki” - kilka uwag o relacjach międzytekstowych powieści Prusa. „Prace Literackie” t. 44 (2004), s. 125. - J. D a m b o r s k ý, Intertekstualność w „Lalce”. „Przegląd Humanistyczny” 2006, nr 5/6, s. 86.

2 D a mborský, op. cit., s. 88. 
Może on zostać zastąpiony aluzją, parafrazą, a nawet cytatem fikcyjnym. Nie cytat jest tu zatem przedmiotem analizy, ale - by tak rzec-jedynie deklaracja podmiotu wypowiedzi: „w tym miejscu przytaczam cudzą wypowiedź" ${ }^{3}$.

Trzecią zaś praktyką jest kryptocytat, który pozostaje niesygnalizowany, a zatem jego rola jest czysto potencjalna, czyli zależna od poziomu kompetencji odbiorcy. Badacz konkluduje:

Wspólną cechą tych zjawisk (tj. cytatu sygnalizowanego, aktu cytowania i kryptocytatów) jest to, że konstytuują semantyczny wymiar istnienia tekstów literackich, chociaż ich funkcje komunikacyjne są zupełnie różne ${ }^{4}$.

Przenosząc ten wniosek w obręb konkretnego utworu, jakim jest Lalka, wypadałoby stwierdzić, iż istnieje pewna zależność między owymi trzema metodami a ich rolą w procesie przekazywania znaczeń. Relacja ta opiera się na założeniu, że im słabszy jest bezpośredni związek cytatu z sytuacją, w jakiej się on pojawia (w szczególności zaś z osobą, która się nim posługuje), tym większa jest jego moc eksplanacyjna czy nawet prefiguracyjna. Wówczas zatem fragment z Pisma Świętego zarówno wyjaśnia, jak i zapowiada dalszy przebieg fabuły, wzbogacając go o aspekt religijny. I odwrotnie: kiedy bohaterowie niemal bezwiednie włączają w swoje wypowiedzi kryptocytaty biblijne, wtedy służą one tylko charakterystyce pośredniej, sygnalizując aktualne stany - a czasem i przemiany - mentalne. Między tymi skrajnymi założeniami znajduje się jeszcze jedno, umiarkowane, związane z koncentracją na akcie cytowania. Wtedy bowiem zarówno pojawia się element postaciowania, jak i - w sposób bardziej ukryty i dlatego fakultatywny - występują procesy interpretacji oraz prefiguracji.

Jedynym bodaj przykładem pierwszego mechanizmu są wydarzenia obejmujące wielkopostną kwestę, w której trakcie Wokulski słyszy aż kilka cytatów biblijnych. Rozwiązanie pośrednie jest częstsze, gdyż narrator nieraz podkreśla samo przywoływanie fragmentów z Pisma Świętego u takich bohaterów jak Wokulski, Izabela, Dalski czy dróżnik Wysocki. Niewątpliwie jednak do najbardziej popularnych przypadków, które dotyczą niemal wszystkich postaci, należą kryptocytaty biblijne. Ponieważ ich funkcja - w przeciwieństwie do zakresu występowania - jest nader ograniczona, pozostają one poza obrębem analiz niniejszego artykułu.

\section{Cytaty sygnalizowane}

Konstrukcja sceny rozgrywającej się w kościele jest niezwykle precyzyjna. Dominantę kompozycyjną stanowi tu zestawienie sfery nadprzyrodzonej - skupiającej się w postaci Chrystusa - z empiryczną, ludzką. Narrator aranżując ten proces wykorzystuje doznania (audytywne oraz wizualne) Wokulskiego ${ }^{5}$, ograniczając

3 W. B o 1 e c k i, Historyk literatury $i$ cytaty. W: Pre-teksty i teksty. Z zagadnień zwiazków międzytekstowych w literaturze polskiej XX wieku. Wyd. 2, zmien. Warszawa 1998, s. 27.

4 Ibidem, s. 28.

5 Jak zauważa Z. Mocarska-Ty cowa (Chrystus $w$ literaturze pozytywizmu. W zb.: Chrystus w literaturze polskiej. Red. P. Nowaczyński. Lublin 2001, s. 303), pisarz prezentuje tu autentyczne doznanie, chociaż podlega ono znamiennym ograniczeniom: „Narrator Prusa jedynie bardziej relatywizuje swój przekaz - doświadczenie obecności Chrystusa przedstawia jako pewnego rodzaju niejasno rozpoznane wrażenie zmysłowe. Narrator informuje, iż bohaterowi w y d a w ało 
przy tym do niezbędnego minimum refleksje bohatera, dla którego sens słyszanych słów jest albo niejasny, albo niewiarygodny. Zasadnicze zadanie bohatera polega bowiem na tym, iż staje się on narzędziem pozwalającym na wykonanie jukstapozycji: kiedy docierają do protagonisty cytaty biblijne, obserwuje on zachowania kolejnych osób (czy grup społecznych) - i dzięki temu tworzy się sugestia związków między tymi sferami.

Przywołane i wyodrębnione cytaty z Nowego Testamentu (bądź ich parafrazy) są w tej scenie liczne, ale można je połączyć w trzy grupy. Do pierwszej należą pojawiające się passusy z Kazania na Górze (I 204, 206, 2116). Mimo ich powtórzenia Prus explicite wprowadza do Lalki jedynie trzy błogosławieństwa, które we współczesnym przekładzie brzmią następująco:

Błogosławieni, którzy się smucą, albowiem oni będą pocieszeni.

Błogosławieni cisi, albowiem oni na własność posiądą ziemię.

Błogosławieni, którzy łakną i pragną sprawiedliwości, albowiem oni będą nasyceni. $[\mathrm{Mt}, 5,4-6]^{7}$

Cytaty te - nieco okrojone - pojawiają się w trakcie obserwacji praktyk religijnych, jakich dokonują przedstawiciele ubogich, najniższych warstw socjalnych. W dalszym przebiegu fabuły fragmenty te będą zatem związane z losami osób, które pochodzą z tych właśnie środowisk.

Druga grupa intertekstów powstała dzięki kontaminacji fragmentów ewangelicznych. Przedstawiając zachowanie prostytutki, narrator stwierdza:

Klęczący obok z niechęcią patrzyli na jej aksamitny kaftanik i jaskrawy kapelusz. Ale gdy Chrystus szepną: „Kto z was jest bez grzechu, niech rzuci na nią kamieniem”, padła na posadzkę i ucałowała jego nogi jak niegdyś Maria Magdalena. [I 204-206]

Połączenie cytatu dotyczącego ukamienowania cudzołożnicy $(\mathrm{J} 8,7)$ z imieniem Marii Magdaleny nie jest zapewne poprawne, ale sugeruje możliwość symultanicznego odniesienia tego cytatu do dwóch różnych kobiet, które znalazły się w podobnej sytuacji, dlatego analogicznie wyrażają swoją wdzięczność. Wskazówkę taką potwierdza obserwacja Wokulskiego, który najpierw dostrzega Marię (,magdalenkę"), a następnie - Helenę Stawską.

Trzecia grupa zakłada jeszcze bardziej radykalną kontaminację biblijnych zapożyczeń. Kiedy bohater wchodzi do kościoła, nie potrafi zidentyfikować się z żadną grupą społeczną. Wówczas ,głos” podpowiada mu:

Może jesteś okiem żelaznego przetaka, w który rzucę ich wszystkich, aby oddzielić stęchłe plewy od ziarna [...]. [I 198]

Zbliżonym nawiązaniem pisarz zamyka tę scenę, tworząc z tych właśnie cy-

s i ę, że owo zjawisko zachodzi, stąd też narrator niejako nie bierze odpowiedzialności za obiektywną prawde przekazu".

6 W ten sposób odsyłam do: B. P r u s, Lalka. Oprac. J. B a c h ó r z. T. 1-2. Wyd. 2, przejrz. Wrocław 1998. BN I 262. Liczby rzymskie oznaczają tomy, arabskie - stronice. Ponadto stosuję w artykule skrót M = J.-L. M a ri o n, Bóg bez bycia. Przeł. M. F r a n k i e w i c z. Wprowadzenie K. Ta r n o w s ki. Kraków 1996. Liczby po skrócie wskazują stronice.

7 Wszystkie cytaty z Biblii podaję za: Pismo Święte Starego i Nowego Testamentu w przektadzie z języków oryginalnych. Oprac. Zespół Biblistów Polskich [...]. Biblia Tysiąclecia. Wyd. 3, popr. Poznań-Warszawa 1980. 
tatów kompozycję klamrową, która podkreśla ich dominującą funkcję. Wokulski słyszy bowiem kolejne proroctwo:

Pośle Syn Człowieczy anioły swoje, a oni zbiorą wszystkie zgorszenia i tych, którzy nienawiść czynią - jako zbiera się kąkol i pali się go ogniem. [I 206]

Józef Bachórz trafnie wskazuje, iż w pierwszej przepowiedni wykorzystana zostaje wypowiedź św. Jana Chrzciciela (Łk 3, 17), natomiast w drugiej bezpośrednio pojawia się odesłanie do wyjaśnienia przypowieści, którego udzielono apostołom (Mt 13, 41-42). Wspólnym tematem pozwalającym na zestawienie obu fragmentów jest kwestia rozróżniania i segregacji, która została ujęta poprzez podobne symbole tworzące pary opozycyjne. Zbieżne okazuje się także to, że obie wypowiedzi zakładają, iż Boska interwencja zostanie dokonana pośrednio: za pomocą „,narzędzia” (pisarz zastąpił tu oryginalne „,wiejadło” - ,przetakiem”) lub „posłańców” (aniołowie).

Połączenie to nie jest zatem bezpodstawne, ale zaskakuje odległymi źródłami. Wydaje się, że uzasadnieniem tego zabiegu (analogicznie do wcześniejszej kontaminacji) jest zwiększenie zakresu odniesienia. Cytaty te bowiem nie tylko wstępnie określają zadanie Wokulskiego, ale także wskazują, że jego działalność odbywać się będzie równocześnie wśród „wszystkich”: tych najuboższych i tych najbogatszych. Przypuszczenie to podtrzymuje też gra spojrzeń bohatera, który, słysząc te fragmenty, nieustannie przenosi wzrok od klęczących biedaków do kwestujących dam (i ich towarzyszy).

\section{Błogosławieńs twa}

Testament Wokulskiego jednoznacznie wskazuje, iż spośród bohaterów pochodzących z warstw najniższych szczególnie bliscy są mu bracia Wysoccy oraz Węgiełek (II 678-679). Wybór ów nie jest przypadkowy, gdyż Wokulski rozpoznawszy wartość wspomnianych ludzi, nie zamierza dopuścić do jej zaprzepaszczenia. Jego działania powodują zatem, że owe trzy błogosławieństwa najtrafniej komentują biografie tych trzech postaci.

Pierwszym ubogim, jakiego spotyka protagonista, jest furman Wysocki. Jego losy układają się wedle sentencji:

Błogosławieni, którzy się smucą, albowiem oni będą pocieszeni. [Mt 5, 4]

W trakcie krótkiej rozmowy (I 168-171) okazuje się, iż niemal wszystkie doświadczenia bohatera wywołują stan, o którym mówi ten passus. Trudności, z jakimi boryka się Wysocki (i jego rodzina), są materialne: brakuje jedzenia, ubrania, odpowiedniego mieszkania. Zarazem jednak pisarz podkreśla, że ten rodzaj nędzy powoduje poważne konsekwencje ${ }^{8}$. Wysocki bez środków do życia oraz pracy nie ma odwagi prosić kogokolwiek (np. Rzeckiego) o pomoc, czując, iż nie jest jej godny. Niepowodzenia odbierają mu wiarę we własne siły i prowadzą do wyniszczającej samotności. Paradoksalnie - jej skutki okazują się widoczne w trak-

8 B. Pru s (Kroniki. Oprac. Z. S z w e y k o w s k i. T. 18. Warszawa 1968, s. 12-13) kwestię tę poruszał wielokrotnie w publicystyce. Najdobitniej sformułował swoje stanowisko w r. 1904, stwierdzając: ,prawdziwa nędza [...] jest nie tylko głodem i chłodem, ale także - niemocą, zwątpieniem i ciężkim żalem do świata, a nawet do Boga!...” 
cie działań charytatywnych: kiedy przynosząca zapomogę siostra negatywnie wypowiada się o statusie moralnym Wysockiego, on nie protestuje; a gdy nieoczekiwanie dostaje pieniądze, jest pewny, że każdy potraktuje go jak złodzieja.

Prus przedstawia zatem człowieka pogrążonego w smutku, którego powodem jest nędza materialna oraz niska samoocena etyczna. Jednakże najbardziej ukrytą przyczyną tego stanu jest alienacja powodująca, że bohater znajduje się na marginesie międzyludzkich relacji. To właśnie doświadczenie utraty - zawarte w podstawowym przesłaniu błogosławieństwa, o którym tu mowa ${ }^{9}$ - sprawia, iż Wysocki natychmiast rozpoznaje Wokulskiego i wita go z nieukrywanymi oznakami szacunku.

Smutek ewangeliczny nie jest stanem egocentrycznym ${ }^{10}$. Dlatego kiedy Wysocki zda relację ze swojego - i nie tylko - położenia, zaniepokoi go także sytuacja Wokulskiego:

Ale i wielmożny pan coś markotnie wygląda? Taki już widać czas nastał, że wszyscy muszą zginąć - westchnął ubogi człowiek. [I 169]

Ten bezinteresowny gest współczucia - tak kontrastujący z niewiele wcześniejszymi uwagami Lisieckiego (I 150-151) - nie tylko zawiązuje solidarne porozumienie między dwoma samotnikami, ale odsłania także najbardziej dramatyczny aspekt ewangelicznego smutku. Zawiera się w nim bowiem doświadczenie umierania, które ogranicza niemal każdy wymiar ludzkiej kondycji ${ }^{11}$.

Drugim ubogim, z jakim styka się Wokulski, jest brat furmana - dróżnik Wysocki. Jego perypetie obrazuje sentencja:

$[\mathrm{Mt} \mathrm{5,6]}$

Błogosławieni, którzy łakną i pragną sprawiedliwości, albowiem oni będą nasyceni.

Trudne położenie Wysockiego wskazuje, iż spośród trzech - przyjmowanych standardowo ${ }^{12}$ - znaczeń kluczowego terminu dominujące jest ostatnie, związane z jakością relacji panujących w społeczeństwie ${ }^{13}$. Nie wiadomo, dlaczego bohater

9 Jak bowiem zauważa współczesny egzegeta, C. M. Martini (Błogosławieństwa. Przeł. S. O b i r e k. Kraków 2000, s. 32): „Słowo greckie - penthoûntes - przywołuje zarówno boleść, jak i smutek, i w sposób bezpośredni odnosi się do żałoby, do łez wylewanych na przykład po śmierci drogiej nam osoby".

${ }_{10}$ Współczesny komentator, P. H i n n e b u s c h (Błogosławieństwa. W poszukiwaniu radości Królestwa Bożego. Przeł. E. P e śl a. Kraków 2004, s. 114), stwierdza: „Dzięki błogosławionemu smutkowi wiemy, czym jest pełna miłości solidarność z cierpiącymi, dlatego pocieszamy zasmuconych". Zob. też S. Tu g w e 11, Osiem błogosławieństw. Rozważania nad tradycją chrześcijańska. Przeł. W. U n olt. Wyd. 2. Poznań 1999, s. 85, 93.

${ }_{11}$ Zob. Tu g w e 11, op. cit., s. 90-91.

12 Jak bowiem stwierdza Martin i (op. cit., s. 59-60): „Możemy [...] powiedzieć, że słowo »sprawiedliwość« zawiera w sobie przynajmniej trzy różne znaczenia. Przede wszystkim chodzi tu o sprawiedliwość Boga, ostateczne zbawienie przez Boga ofiarowane wszystkim ludziom. Na drugim miejscu jest sprawiedliwość człowieka, jego dobre, pobożne uczynki - przestrzeganie praw, jałmużna, świętość moralna. I wreszcie jest sprawiedliwość społeczna, stosunki międzyludzkie oparte na sprawiedliwości”.

${ }_{13}$ Taką sugestię potwierdzają późniejsze wypowiedzi Prusa, w których pojawia się to błogosławieństwo. Np. omawiając wysiedlenia i represje Polaków, jakie w Księstwie Poznańskim organizowali hakatyści, pisarz zauważa istnienie motywacji religijnej dla tych działań. Starając się ją zdyskredytować, ironicznie stwierdza: „W taki sposób modli się do Chrystusa, który między innymi 
został przez władze Kolei Warszawsko-Wiedeńskiej przeniesiony pod Częstochowę, prawdopodobnie powód był akcydentalny lub biurokratyczny. Nikt jednak nie zwrócił uwagi na straty, jakie ta decyzja spowodowała w uposażeniu Wysockiego, który tę samą pracę wykonuje teraz w niekorzystnie zmienionych warunkach. Przeprowadzka oznacza bowiem dla niego rezygnację z uprawy posiadanej ziemi, dzięki czemu nie tylko nie jest $\mathrm{w}$ stanie nadal pomagać rodzinie brata, ale i sam znajduje się w katastrofalnej sytuacji. Sprawiedliwym rozwiązaniem byłoby zwiększenie wynagrodzenia, lecz takiej propozycji nikt Wysockiemu nie składa.

Trzecim ubogim jest Węgiełek, stolarz z Zasławia. Do jego postawy znajduje zastosowanie ostatni passus:

Błogosławieni cisi, albowiem oni na własność posiądą ziemię. [Mt 5, 5]

Węgiełek przynajmniej dwukrotnie mógł zaangażować się w konflikt. Narrator dyskretnie przemilcza wprawdzie kwestię przyczyn podpalenia warsztatu, ale należy się domyślać, iż jego sprawcą okazał się małomiasteczkowy konkurent zdolnego rzemieślnika ${ }^{14}$. Węgiełek jednak poprzestaje na zwykłym wyładowaniu swej złości (II 295), nie szukając na nikim zemsty. Niemal identycznie zachowa się wobec Starskiego, chociaż tym razem zaniechanie odwetu za krzywdy wyrządzone Marii wywoła u tego bohatera najpierw gniew, a następnie emocjonalną apatię względem żony (II 602-604).

Jeśli podstawowym sensem cichości ewangelicznej jest unikanie przemocy w sytuacjach, które mogą do niej prowadzić ${ }^{15}$, to Węgiełek wypełnia to zadanie znakomicie $^{16}$, zwłaszcza że nie jest to łatwe z powodu jego temperamentu. Postępowanie względem Marianny wskazuje ponadto, iż jej przyszły mąż nie tylko rezygnuje z działań gwałtownych, ale potrafi współczuć tym, którzy stali się ich ofiarą. Jego litość przeradza się w odwzajemnioną miłość ${ }^{17}$; a przemiana ta jest

uczył: [...] »Błogosławieni, którzy łakną sprawiedliwości, albowiem będą nasyceni...«" (P r u s, Kroniki, s. 17).

${ }^{14}$ Jak bowiem przekonuje J. Z a c har s k a (Pożary u Prusa. W zb.: Prus i inni. Prace ofiarowane profesorowi Stanistawowi Ficie. Red. J. A. Malik, E. Paczoska. Lublin 2003, s. 206): „pożary w utworach Prusa nie są dziełem natury lub przypadku, lecz wynikiem działania ludzi [...]”.

${ }_{15} \mathrm{M}$ a r ti in i (op. cit., s. 50) zauważa: ,„Cichość« jest zdolnością zrozumienia, iż w stosunkach międzyludzkich - a one przecież określają właściwy człowiekowi poziom istnienia - nie ma miejsca na przymus czy przemoc; tutaj bowiem skuteczna jest pasja przekonywania i ciepło miłości. [...] Cichość staje się więc przeciwieństwem wszelkiej formy przemocy fizycznej czy moralnej; staje się zwycięstwem pokoju nad wojną, dialogu nad gwałtem".

${ }_{16}$ O tym, iż Prus rozumiał to błogosławieństwo w sensie ,pacyfistycznym”, świadczą też jego uwagi dotyczące konfliktów zbrojnych. Potrzebę ich zaniechania w przypadku Anglików uzasadniał następująco: „Naród, dla którego Biblia stanowi najulubieńszą książkę, zapomniał przemądrych słów Chrystusa: »Błogosławieni cisi, albowiem oni odziedziczą ziemię!«” (B. P r u s, Kroniki. T. 16 〈1966〉, s. 494). Nb. pisarz w tym względzie diametralnie różni się od A. Świętochowskiego. Autor Dumań pesymisty tę sentencję interpretował dosłownie, stosując ją do skromnego i działającego w ukryciu społecznika, który: „Zaparł się własnego istnienia, rozpłynął się w istnieniu tysiąców. Nie żyje przez siebie i dla siebie, żyje przez dusze swych braci i tylko dla nich. Struny swego serca związał ze strunami społeczeństwa i odtąd każde wewnętrzne drgnienie tego ostatniego odzywa się właściwym dźwiękiem i w jego piersi” (A. Ś w i ę t o c how s k i, Błogosławieni cisi... „Przegląd Tygodniowy” 1872, nr 21). Zob. też M. Kr e f t, Elizy Orzeszkowej „Błogosławieni cisi...” W zb.: Twórczość Elizy Orzeszkowej. Red. K. Stępnik. Lublin 2001.

17 Dla współczesnych komentatorów istnieje bliski - i nadprzyrodzony - związek między cichością a miłością. Np. J.-M. L u s ti g e r (Bądźcie szczęśliwi. Przeł. I. K róli k. Kraków 1999, 
o tyle ważna, o ile nie pozostaje bez dalszych konsekwencji. Podejmując decyzję o małżeństwie, Węgiełek akceptuje przecież ryzyko, jakie wiąże się z dawnym postępowaniem „magdalenki” (II 467-468).

Błogosławieństwa ewangeliczne wskazują na stan szczęścia, który, jak podkreślają egzegeci ${ }^{18}$, należy rozumieć zarówno subiektywnie, jak też obiektywnie. Prus migawkowo przedstawiając dalsze losy tych epizodycznych postaci, niezwykle precyzyjnie prezentuje oba te wymiary. Pierwszy z nich jest związany z postępowaniem Wokulskiego, który w odpowiedni sposób pomaga potrzebującym. Natomiast drugi, istotniejszy aspekt jest trudniej zauważalny, dlatego jego ukazanie wymaga dodatkowego kontekstu.

Najszybciej obietnica ewangeliczna zostaje zrealizowana w przypadku furmana Wysockiego. Wokulski natychmiast wręcza mu zapomogę, a następnego dnia każe mu stawić się w swoim sklepie. Łzy, jakie pojawiają się na twarzy Wysockiego, wyrażają zarówno wdzięczność za niespodziewane ocalenie, jak i - paradoksalnie - szczęście. Oto bowiem znalazł się ktoś, kto nie tylko nim nie pogardza, ale troszczy się o niego.

Jego brat dróżnik czeka nieco dłużej. Ostatecznie jednak Wokulskiemu udaje się przenieść go do Skierniewic, a administracja Kolei Warszawsko-Wiedeńskiej naprawia niesprawiedliwość, podwyższając wynagrodzenie. Nie jest zresztą wykluczone, iż pisarz, wprowadzając informację o działalności gastronomicznej Wysockiego (I 504), sugeruje pełne - dlatego także dosłowne - spełnienie biblijnej zapowiedzi.

„Ziemia”, o jakiej mówi ostatnie błogosławieństwo, również zawiera element nie tyle materialny, ile związany z codzienną egzystencją. Węgiełek, przebywając pod opieką Wokulskiego, nie tylko uzyskuje środki na odbudowę spalonego warsztatu, ale i nabywa kolejnych umiejętności, które po powrocie uczynią go jeszcze lepszym rzemieślnikiem. O wiele ważniejszy jest jednak fakt, iż dzięki pobytowi w Warszawie spełni się pragnienie Węgiełka związane ze znalezieniem żony ze sfery mieszczańskiej. Ponadto, jeśli błogosławieństwo zapewnia, że otrzymane dary staną się własnością obdarowanego, oznacza to, iż Węgiełek nie straci już ani swoich kwalifikacji, ani miłości, jaką ofiarowuje mu Marianna.

Obserwacja zachowań tych bohaterów prowadzi wszelako do wniosku, że otrzymana pomoc wywołuje $\mathrm{u}$ nich przemianę. Dokonuje się ona na poziomie psychologicznym, ale jej interpretacja wymaga, jak sądzę, uwzględnienia także kontekstu teologicznego. Wydaje się, iż przedstawiając obiektywne skutki działania błogosławieństw, Prus pozostaje zgodny z tradycyjną teologią św. Augustyna, który Kazanie na Górze połączył z darami Ducha Ś więtego ${ }^{19}$.

s. 57) konkluduje: „Jeśli »cisi« mogą zostać nazwani błogosławionymi, to dlatego, że Bóg udziela im swojej siły miłości po to, aby uczestniczyli w Jego zamyśle".

18 Najtrafniej wyraził to L u s t i g e r (ibidem, s. 107), stwierdzając, iż błogosławieństwa „uczą, czym jest szczęście o b i e k t y w n i e: ma ono swe źródło w Bogu i polega na zjednoczeniu się z Jego Synem. Jak jednak przyjąć podobne stwierdzenie, skoro szczęście jest z zasady s u b i e k t y w n e? Rzeczywiście, nie za bardzo można być szczęśliwym, niczego z tego szczęścia nie odczuwając [...]".

19 Św. A u gu s t y n, Błogosławieństwa a dary Ducha Świętego. W: O kazaniu Pana na górze. - Do Symplicjana o różnych problemach. - Problemy ewangeliczne. Przeł. S. R y z n a r, J. S u 1k o w s ki. Wstęp, oprac. E. S t a n u la. Warszawa 1989, s. 26-29. 
Wedle autora Wyznań ci, którzy nazwani są smutnymi, otrzymują dar umiejętności. Jeśli jego rozumienie zawiera także pragmatyczną intuicję, to Prus koncentruje się przede wszystkim na niej. Doraźna pomoc udzielona Wysockiemu powoduje bowiem, iż zostaje on wyrwany ze stanu apatii. Staje się osobą zaradną i przedsiębiorczą, dlatego narrator nie wspomina, kiedy i w jakich okolicznościach bohater Lalki przeniósł się z Powiśla na Tamkę. Natomiast kolejne polecenia Wokulskiego spełnia Wysocki biegle i skrupulatnie, nawet jeśli nie zawsze rozumie intencje swojego dobroczyńcy.

Męstwo staje się udziałem poszukujących sprawiedliwości. Dróżnik Wysocki najpierw zachęca swojego syna do przyjęcia takiej postawy (I 299), a następnie sam daje dowód odwagi, ratując Wokulskiego przed samobójczą śmiercią na torach. Interpretując późniejszą rozmowę bohaterów (II 528-532), można stwierdzić, iż akt ten łączy wszystkie trzy sensy sprawiedliwości ewangelicznej, pokazując, że jej wypełnianie wymaga determinacji i niezłomnej woli, której działanie nie obywa się bez motywacji religijnej ${ }^{20}$.

Natomiast cichym przeznaczony zostaje dar pobożności. Szczególnie widać go w ostatnim dokonaniu Węgiełka, który przeszukawszy dokładnie zasławskie ruiny, stawia na nich krzyż upamiętniający ocalenie Wokulskiego (II 685-686). Węgiełek jest więc przekonany, iż ten bezsporny fakt nie miałby miejsca, gdyby nie wpisano go w Boski plan odkupienia.

Wydaje się zresztą, iż na takie postępowanie bohatera wpływa jego aktualna sytuacja rodzinna, w której dokładnie wypełnia się błogosławieństwo ewangeliczne. $Z$ listu wynika bowiem, że relacje Węgiełka z żoną uległy znaczącej poprawie, gdyż stara się on teraz rozumieć jej obawy, uczucia, reakcje. Ta zmiana byłaby niemożliwa ${ }^{21}$, jeśli w nim samym nie dokonałoby się odnowienie dawnej więzi, jaka po spotkaniu ze Starskim wydawała się zaprzepaszczona. Węgiełek znów jest sobą ${ }^{22}$ - człowiekiem wrażliwym i zaangażowanym - a zarazem kimś lepszym, ponieważ wyzbywając się egocentryzmu, odkrywa miłość, która zawsze szuka dobra ukochanej osoby.

\section{Jawnogrzesznice}

Między Marią a Heleną Stawską istnieją ważne różnice, ale perspektywa intertekstu ewangelicznego podkreśla raczej podobieństwa ich sytuacji. Cztery kluczowe momenty ich biografii są więc analogiczne: konflikt z osobą wyżej od

${ }^{20}$ Zob. S. F it a, ,Pozytywista ewangeliczny”. Problematyka religijna w twórczości Bolesława Prusa. W: „, Pozytywista ewangeliczny”. Studia o Bolesławie Prusie. Lublin 2008, s. 28.

${ }^{21}$ Jej konieczność trafnie dostrzega B. O b s u le w i c z-N i e w iń s k a (,Nieobałamucona” wrażliwość. Pisarze okresu pozytywizmu o filantropii i miłosierdziu. Lublin 2008, s. 279), stwierdzając: „Nie tylko Maria musi się zmienić. Jej metamorfoza jest zależna od metamorfozy Węgiełka. Jest, by odwołać się do skrótu myślowego, zależna od oczu Węgiełka”.

22 Współczesny egzegeta, S. Th. P i n c k a e r s (Szczęście odnalezione. Przeł. P. S i e j k o ws k i. Poznań 1998, s. 64), wskazuje, iż „ziemia” zawarta w tym błogosławieństwie jest niewątpliwie „królestwem niebieskim, o którym mówił Jezus, wypełniając starotestamentalną obietnicę. Lecz czy nie oznacza ona również owego cichego posiadania samego siebie, ziemi naszego ciała i naszego serca, które jest udziałem tych, którzy będąc wydani łagodności Boga, nauczyli się wyrzucać z duszy i życia przemoc, chaos i podziały, rozsiewane przez grzech? Czy owocami Ducha nie są radość, spokój, łagodność, opanowanie?” 
nich postawioną, publiczne potępienie, które jest jego wynikiem, udzielona w chwili krytycznej pomoc Wokulskiego oraz wdzięczność, jaką te kobiety wyrażają wobec wybawcy.

Obie bohaterki zostają oskarżone o kradzież (dochodów, lalki) przez swoje pracodawczynie. W dwóch przypadkach pomówienie jest fałszywe i - jak pokazują szerzej przedstawione losy Stawskiej - stanowi ono formę zemsty, która wynika z zazdrości. Pomimo to skutki owych zachowań są radykalne: szantażowana Maria zostaje prostytutką, a Helenie grozi udowodniona sądownie wina pociągająca za sobą utratę środków utrzymania i, prawdopodobnie, eksmisję. Maria już jest na marginesie zarezerwowanym dla najgorszych, a Stawska powoli zmierza w podobnym kierunku. Analogia staje się zresztą ściślejsza, jeśli uwzględni się jej aspekt moralny. Usunięcie czy usuwanie poza nawias obu kobiet okazuje się bowiem dodatkowo uzasadniane ich niewłaściwym obyczajowo zachowaniem, które jest albo oczywiste (prostytucja), albo domyślne (romanse).

Postępowanie Wokulskiego w tych sytuacjach także jest podobne przynajmniej do tego stopnia, jaki sugeruje pytanie ewangeliczne $(\mathrm{J} 8,7)$. Jego sens dokładniej odsyła wprawdzie do sytuacji Heleny Stawskiej: jej główna oskarżycielka, baronowa Krzeszowska, zostaje skompromitowana. Ujawniony zostaje bowiem zarówno fałszywy charakter jej pomówienia, jak też jego ukryte intencje, które daleko odbiegają od norm etycznych.

Natomiast przypadek Marii jest trudniejszy. Niewątpliwie, wyraźna niechęć, jakiej wobec niej doświadcza bohater, wynika z trafnej obserwacji, zgodnie z którą owa kobieta także w kościele okazała się prostytutką ${ }^{23}$. Niemniej - nie Wokulski pierwszy rzuca w nią kamieniem: on tylko odkrywa, że Maria na obecnym etapie niczym nie różni się od tych, którzy ją wykorzystują. Jeśli jej „cyniczna historia” jest prawdziwa, to oznacza, iż bohaterka zapamiętale szuka zemsty - i w tym celu posunie się nawet do świętokradztwa. Publicznie potępia zatem samą siebie, ponieważ zamierza uzyskać Boską pomoc $\mathrm{w}$ walce $\mathrm{z}$ osobami, których szczerze nienawidzi. Działanie Wokulskiego jest tu proste, a zarazem skuteczne: odkrywając sytuację Marii, czyni on wszystko, aby radykalnie odseparować ją od ludzi, z którymi pozostaje w konflikcie.

W obu przypadkach postępowanie bohatera dalekie jest od spontaniczności, ale jego zaangażowanie w proces sądowy jest zdecydowanie silniejsze. Dlatego też wdzięczność, jaka spotka Wokulskiego, okazuje się proporcjonalna do jego nastawienia. Maria modli się za niego, a w trakcie ostatniej rozmowy z trudem powstrzymuje łzy wzruszenia. Natomiast późniejsze postępowanie Stawskiej okaże się dla protagonisty jedynym źródłem wytchnienia i zapomnienia o bólu, który osacza go podczas pobytu na arystokratycznych salonach (II 442, 482). Pani Helena - niczym ewangeliczna Maria (J 12, 3) - w swoim domu oferuje Wokulskiemu ostatnie chwile spokoju przed nadchodzącym apogeum cierpienia.

\section{Zgorszenia}

Przytoczony przez Prusa cytat z Ewangelii (I 206) brzmi w wersji dokładnej następująco:

${ }^{23}$ Zob. Obsulewi c z-Nie wińska,op. cit., s. 465. 
Syn Człowieczy pośle aniołów swoich: ci zbiorą z Jego królestwa wszystkie zgorszenia i tych, którzy dopuszczają się nieprawości, i wrzucą ich w piec rozpalony; tam będzie płacz i zgrzytanie zębów. [Mt 13, 41-42]

W kontekście fabularnym kluczowe jest tu owo ,zgorszenie” czy, jak niekiedy termin ten bywa przekładany, ,skandal”. Jego antropologiczny sens został interesująco przedstawiony przez René Girarda:

Grecki termin ,skandalon”, jak i jego hebrajski oryginał, oznacza nie jedną z tych zwyczajnych przeszkód, którą człowiek bez trudu omija, jak już się raz o nią potknie, lecz paradoksalną przeszkodę, której prawie że nie daje się uniknąć. Im bardziej bowiem zgorszenie nas odrzuca, z tym większą mocą nas pociąga. Im bardziej wcześniej się potłukliśmy, z tym większym zapałem rozbijamy się znowu.

Aby pojąć ten dziwny fenomen, wystarczy nawet w tym, co właśnie napisałem, rozpoznać zachowanie mimetycznych rywali, którzy zakazując sobie nawzajem przedmiotu swego pożądania, jeszcze umacniają w sobie swoje podwójne pragnienie. Systematycznie przeciwstawiając się sobie, aby uniknąc nieubłaganej rywalizacji, zawsze w końcu potykają się o fascynującą przeszkodę, którą odtąd są dla siebie nawzajem²4.

Girard podkreśla przy tym utratę samostanowienia przez podmiot, który został zgorszony:

„Skandalon” oznacza zatem niezdolność uniknięcia ducha rywalizacji, który w rzeczywistości jest duchem niewoli, ponieważ podporządkowuje nas tym wszystkim, którzy nas przewyższają, a my nie dostrzegamy, jak niewiele warta jest cała ta gra $^{25}$.

To ograniczenie okazuje się ważne, ponieważ w Lalce Wokulski także jest uwikłany w skandal, który zawęża jego perspektywy poznawczą i emocjonalną ${ }^{26}$. Z faktu, iż bohater nie znajduje się - przynajmniej w zasadniczej partii fabuły - poza skandalem, wynikają trudności dotyczące funkcjonowania passusu ewangelicznego. Czy owym Boskim pośrednikiem niwelującym zgorszenia będzie Wokulski?

Odpowiedź jest, jak sądzę, paradoksalna: i tak, i nie. Nie, jeśli sytuacja taka wymagałaby od protagonisty doskonałej (,,anielskiej") postawy, wolnej od rywalizacji, dzięki czemu mógłby on konsekwentnie realizować pokojową misję ${ }^{27}$. Tak, jeśli założy się, że jego nie zawsze właściwe czyny - niekiedy mimowolnie, a niekiedy nie - będą oddziaływać na innych w taki sposób, że doprowadzą do spełnienia proroctwa ewangelicznego. Metafora ,przetaka”, jaką wybrał Prus, jest więc szczególnie adekwatna: bohater, owszem, będzie narzędziem, ale nieco mechanicznym, bezwiednym, a nawet - jak sugeruje wypowiedź, która ową metaforę zawiera-biernym.

Interpretację taką wspiera także sens biblijnego cytatu, sens, którego nie można ujmować tradycyjnie, czyli eschatologicznie ${ }^{28}$. Gdyby dotyczył on wyłącznie

${ }^{24}$ R. G ir a rd, Widziałem szatana spadającego z nieba jak blyskawica. Przeł. E. B u r s k a. Warszawa 2002, s. 29.

${ }_{25}$ R. G i r a rd, Poczatki kultury. Przeł. M. R o m a n e k. Kraków 2006, s. 139.

${ }^{26}$ Szerzej piszę o tej kwestii w książce Powracająca fala. Mityczne konteksty wybranych powieści Bolestawa Prusa i Elizy Orzeszkowej (Kraków 2005).

27 Dlatego zbyt ryzykowny jest sąd M. G 1 o g e r a (Bolesław Prus i dylematy pozytywistycznego światopogladu. Bydgoszcz 2007, s. 208), który stwierdza, iż w Lalce: „Parafrazy ewangelicznych sentencji zostają podporządkowane głównemu bohaterowi i służą jego charakterystyce jako herosa powołanego do walki ze złem, przemiany duchowej ludzkości i ustanowienia nowego porządku, a przez to niemal równego Jezusowi”.

${ }^{28}$ Tak właśnie postępuje To k a r zó wn a (op. cit., s. 54). 
Sądu Ostatecznego, wtedy jego wprowadzenie do fabuły umieszczonej w perspektywie doczesnej byłoby zupełnie niefunkcjonalne. Zrozumienie tego zabiegu umożliwia najnowsza egzegeza, która komentuje ów fragment następująco:

Odnośnie do tej przypowieści [...] należałoby się zastanowić, co oznaczałaby, gdyby zamiast informacji o k oń c u, była raczej nauczaniem dotyczącym tego, jak żyć tu $\mathrm{i}$ teraz, w okresie przed końcem. W tym przypadku rola owej opowieści jest nieco inna. Zamiast wyposażać nas w detale sądu po śmierci, upiera się ona, żeby n i e w y k o n y w ać ża d n ego typu sądu przed śmiercią. Kiedy ona mówi: „Tam będzie płacz i zgrzytanie zębów”, nie traktujmy tego jako straszenia, ale jako zachętę: „Zostaw in n e m u powodowanie płaczu i zgrzytania zębów. Niech to będzie t a m, a nie tu. Nie czyń t e r a z żadnego rodzaju sądu lub segregacji między dobrymi i złymi ludźmi. W ten sposób będziesz budował Królestwo Niebieskie" ${ }^{29}$.

Taką postawę przyjmuje - albo stara się przyjąć - protagonista wobec pewnych postaci, które (podobnie jak on) tkwią w sferze skandalu. Jednakże te zgorszenia nie mogą się ze sobą krzyżować: jeśli bowiem tak się dzieje, Wokulski zamiast powstrzymywać się od wrogich działań, dokonuje ich intensyfikacji (np. konflikt ze Starskim). Dlatego korzystny wpływ Wokulskiego jest wyraźny tylko w przypadku dwojga osób - barona i baronowej Krzeszowskich. Oddziaływanie to zgodnie z przesłaniem ewangelicznym można określić jako wyzwolenie postaci spod władzy zgorszenia, które dotąd panowało w jej egzystencji niepodzielnie.

\section{Baron Krzeszows ki}

Pojedynek nie jest wydarzeniem autonomicznym, dotyczącym jedynie samych zainteresowanych. Jego kluczowym kontekstem są bowiem stosunki między baronem a panną Łęcką, które narrator podsumowuje następująco:

Krzeszowskiego nienawidziła panna Izabela. Kiedyś umizgał się do niej, a odtrącony, mścił się. Wiedziała, że nazywał ją za oczy - starzejącą się panną, która wyjdzie za swego lokaja. Tego było dosyć, ażeby pamiętać mu całe życie. Lecz baron, nie poprzestając na nieszczęsnym frazesie, nawet wobec niej zachowywał się cynicznie, drwiąc z jej starych wielbicieli i robiąc aluzje do ich majątkowej ruiny. Że zaś i panna Izabela od niechcenia przypominała mu jego żonę, mieszczankę, z którą połączył się dla pieniędzy, a nic od niej nie mógł wydobyć, więc - toczyła się między nimi walka ostra, czasami nawet przykra. [I 450]

Ten konflikt ma naturę ewangelicznego skandalu: obie strony nie mogą zrezygnować z cyklicznych działań prowadzonych przeciwko sobie. Krzeszowski zakłada, iż przyczyną odrzucenia jego starań okazał się domniemany rywal, dlatego usiłuje go zdyskredytować, publicznie odmawiając mu wszystkiego (majątku, urodzenia itp.). Ponadto baron przenosi antagonizm małżeński, czyniąc Izabelę odpowiedzialną za swój stan majątkowy; ją także traktuje jak rywala pilnie skrywającego przed nim potrzebne fundusze. Wynikające z takiej motywacji działania bohatera powodują u panny Łęckiej eskalację nienawiści, która staje się obsesyjna i prowadzi do powstawania kolejnych planów zemsty lub upokorzenia.

Wokulski, dzięki pani Meliton, korzysta z takiego właśnie projektu Izabeli, który dotyczy klaczy wyścigowej. Wykonanie tego zamiaru okazuje się perfekcyj-

29 J. A 1 i s o n, Raising Abel. The Recovery of the Eschatological Imagination. New York 1996, s. $84-85$. 
ne, gdyż, jak zaznacza narrator, po wygranej gonitwie barona spotykają klęska i wstyd. Wszelako reakcja Krzeszowskiego jest i przewidywalna, i natychmiastowa: w odwecie publicznie zniesławia on Stanisława jako „wielbiciela” oraz „dobroczyńcę", który pozbawia go zarówno zwycięstwa, jak też pieniędzy.

Protagonista został zatem wciągnięty w konflikt arystokratyczny, dlatego jest zmuszony do zachowań zgodnych z jego zasadami. W każdej zaś walce po ataku następuje kontratak, stąd wyzwanie barona na pojedynek wydaje się postępowaniem konsekwentnym i nieuchronnym. Ważniejszy jest jednak fakt, iż Wokulski przejmuje nie tylko formy działania, ale również ich motywacje: zupełnie nie znając Krzeszowskiego, odczuwa względem niego „głuchą wściekłość” (I 419), a tuż przed pojedynkiem - „dziką zajadłość” (I 423).

Dopiero kiedy baron przypadkowo spudłuje, owo negatywne nastawienie ulegnie redukcji, dzięki której radykalny odwet zostanie przez Wokulskiego zaniechany. Symbolika jego strzału wcale nie jest groteskowa ${ }^{30}$, ponieważ objawia, iż bohater - niczym ów pistolet - okazuje się narzędziem, tj. osobą trzecią, która jedynie przenosi (oraz intensyfikuje) zadawnione resentymenty.

Rozpoznanie tej kwestii powoduje, że pan Stanisław już względem rannego Krzeszowskiego zachowa się nadzwyczaj przyjaźnie, a nawet poprosi go o przebaczenie (I 425). Niemal ze wstydem wyzna baronowi właściwą przyczynę pojedynku, uzyskując - szybko zrealizowaną - zapowiedź przeprosin i pojednania z Izabelą (I 458-459). Długotrwały skandal zostaje więc przerwany: Krzeszowski i panna Łęcka zapominają o wzajemnych urazach, a ich relacja wkracza w nowy etap.

Podszyte zawiścią malwersacje finansowe Maruszewicza sprawiły jednak, iż baron ponownie zraził się do Wokulskiego, który rzekomo pozbawił go 200 rubli. Ta „kupiecka” natura stanie się kolejnym źródłem zgorszenia, każąc Krzeszowskiemu - ze szkodą zresztą dla siebie - unikać pana Stanisława, a także rozpowszechniać o nim niepochlebne opinie na salonach.

Gdy tę sprawę przejmie Rzecki, ujawnione zostanie oszustwo, którego dopuścił się Maruszewicz. Skruszony baron sam wtedy przyjdzie do Wokulskiego, odbywszy uprzednio serię wizyt, w których trakcie odwołał fałszywe posądzenia (II 503-504). Między bohaterami dochodzi wówczas do trwałego pojednania i obaj traktują się już jak członkowie jednej rodziny, w której szczerze rozmawia się o finansowych sekretach. Pan Stanisław - podobnie jak poprzednio baron w stosunku do Izabeli - podejmie także ugodowe działania względem Maruszewicza.

Między Wokulskim a Krzeszowskim dwukrotnie zatem dochodzi do konfliktu, który kończy się wspólnym porozumieniem. To powtórzenie nie stanowi retardacji: w obu bowiem sytuacjach bohaterowie kolejno zostają wciągnięci do uprzednich antagonizmów, których funkcjonowanie potrafi przeciwstawić sobie albo niemal obce, albo nawet oficjalnie już pogodzone osoby. Niezwykła jest więc siła, z jaką zgorszenia potrafią się rozprzestrzeniać, zwłaszcza jeśli ich „terenem” jest zamknięta społeczność. Wydaje się to o tyle ważne - i zaskakujące - o ile oba przypadki nie należą do idealnie symetrycznych, gdyż w drugim napięcia są słabsze, wyłącznie jednostronne (Maruszewicz i baron przeciwko Wokulskiemu, ale nie odwrotnie).

${ }^{30}$ Zob. J. B a c h ó r z, Pojedynek Stanisława Wokulskiego z baronem Krzeszowskim. (Z cyklu: Kolejne zabawy „Lalka”). W zb.: Nowe stulecie trójcy powieściopisarzy. Red. A. Z. Makowiecki. Warszawa 1992, s. 135. 
Baronowa Krzeszowska

Baronowa również tkwi w podwójnym układzie napięć, lecz - inaczej niż mąż - nie łączy ich ze sobą. Skandaliczna natura przysługuje tylko pierwszemu z tych układów, który obejmuje relacje bohaterki z jej mieszkającymi na poddaszu sąsiadami. Baronowa i studenci nie tracą żadnej okazji, aby pod pretekstem tej samej moralności wzajemnie się znieważać, oskarżać czy wreszcie uciekać się do drobnych, acz bardzo nieprzyjemnych działań. Prus przedstawiając te utarczki, kładzie nacisk na ich komiczny, wręcz groteskowy aspekt, niemniej ów „rodzaj sportu” (II 331) polegający na szybkim ataku i jeszcze szybszym uniku okazuje się dla wszystkich uzależniający; młodzieży dostarcza on rozrywki, a u Krzeszowskiej wywołuje spazmatyczne ataki, jednakże żadna ze stron nie zamierza ustąpić. Dopiero eksmisja studentów - możliwa tylko dzięki postępowaniu Wokulskiego w sprawie kamienicy - kładzie kres temu konfliktowi, który po ich nieoficjalnym powrocie zostanie odnowiony, chociaż kto inny (zamiast baronowej) będzie w niego zaangażowany.

Antagonizm z sąsiadami nie jest dla Krzeszowskiej uciążliwy, ponieważ paradoksalnie okazuje się zarazem intensywny, jak też powierzchowny. Silna nienawiść bohaterki omija bowiem studentów i koncentruje się na osobie Heleny Stawskiej, która jednak w żaden sposób nie odwzajemnia tego nastawienia. Zgorszenie jest zatem jednostronne, ale - inaczej niż u męża - nie zmniejsza to wrogości baronowej, wręcz przeciwnie: podsyca ją.

Pierwsza faza zgorszenia polega na zazdrości o Krzeszowskiego, który, wyprowadziwszy się z domu, okazuje pani Helenie wyraźne zainteresowanie. Dezaprobata, z jaką traktuje ona te starania, wcale nie zmniejsza jej winy względem baronowej. Krzeszowska bowiem ocenia to zachowanie dokładnie tak, jak gdyby sama była jego wykonawczynią; ponieważ zaś teatralizacja jej postępowania jest absolutna $^{31}$, dlatego bezwiednie baronowa projektuje analogiczną postawę na działania Stawskiej, która, wyrzucając kwiaty od barona, jedynie „udaje” i „oszukuje" wszystkich (II 75). Czyniąc z niej swoje alter-ego ${ }^{32}$, Krzeszowska natychmiast popada w skrajny resentyment. Uniesiona gniewem apeluje do Rzeckiego:

Panie! - wybuchnęła z nową siłą głosu - możesz zostawić nawet tych nihilistów, ale ją... musisz wygnać!... Niech lokal stoi po niej pustką... będę za niego płacić, byle ona nie miała dachu nad głową... [II 82]

Ten wybuch nienawiści jest autentyczny i nader znamienny: kiedy zazdrość przemieni innego w sobowtóra, podmiot doprowadzony zostaje do stanu, w którym przemoc jawi się jako jedyny skuteczny sposób postępowania. Oczywiście, sama zainteresowana nie wykona tego zamierzenia, chętnie natomiast posłużyłaby się w tym celu osobami trzecimi.

Gdy jednak starania barona osłabły (albo nawet zostały zaniechane), baronowa wróciła do kwestii, która już wcześniej ją angażowała. Przegrywając licytację,

31 Zob. A. Z. B u d r e w i c z, Krzeszowska-krewna Dulskiej? W zb.: Świat „Lalki”. 15 studiów. Red. J. A. Malik. Lublin 2005.

${ }^{32}$ Podobieństwo sytuacji, a zarazem lepsza pozycja Stawskiej wobec Krzeszowskiej są przez narratora stale podkreślane. Obie bowiem kobiety nie są ,ani rozwódkami, ani wdowami” (II 91), ale tylko pierwsza wciąż cieszy się zainteresowaniem mężczyzn; obie też mają rozwinięty instynkt macierzyński (dotyczący córek), lecz jedynie pani Stawska może go realizować. 
postanowiła zdobyć kamienicę, ponieważ traktuje ją niczym relikwię po zmarłej córeczce. Teraz to Wokulski swoim uporem dotyczącym ceny nieustannie gorszy Krzeszowską, wyzwalając w niej równie silną - jak wynika z anonimów - nienawiść. Bohaterka i tym razem będzie działała za pomocą pośredników, a najważniejszym z nich okaże się właśnie pani Stawska. Złożona jej propozycja pracy ma na celu zawiązanie znajomości, która mogłaby być wykorzystana do wywarcia odpowiedniego wpływu na Wokulskiego. Paradoks tej sytuacji polega na tym, iż dotychczasowy „kamień obrazy” - czyli uroda pani Heleny - nagle staje się dla Krzeszowskiej cennym i pragmatycznym atutem, wobec którego ustępuje nawet kwestia moralności.

Początkowe niepowodzenie nie zniechęca baronowej, dlatego postanawia włączyć w swój plan także córkę Stawskiej - Helenkę. Zaprasza ją razem z matką i wypytuje o Wokulskiego, licząc, iż ten nie odmówi prośbie przekazanej przez dziecko. Kiedy więc te wysiłki stały się daremne, Krzeszowska drogo kupiwszy kamienicę nie tylko wypowie mieszkanie Stawskiej, ale wykorzysta nadarzającą się - tzn. podsuniętą przez Maruszewicza - sposobność do zemsty, która dosięgnie tyleż matkę, ile córkę.

Jest w tym postępowaniu coś okropnego; jeśli bowiem baronowa zamierza wykorzystać Helenkę, musi przekazać jej własne nastawienie do Wokulskiego czy Rzeckiego. Częściowo udało się jej już tego dokonać (II 358), ale gdyby wizyty trwały dłużej, nie jest wykluczone, iż córeczka Stawskiej ostatecznie uległaby tej perswazji. Przenoszenie na niewinne dzieci (a Helenka niewątpliwie do nich należy) „dorosłych" resentymentów to deprawacja, wciąganie w krąg skandalu ${ }^{33}$. W tym kontekście kulminacyjną scenę procesu, kiedy sędzia na oczach przerażonej Helenki niszczy ową lalkę, można ująć symbolicznie: destrukcji podlega nie tyle przedmiot, ile te odczucia dziecka, które zostały skażone działaniami baronowej.

Upokorzenie doznane w sądzie okazało się dla Krzeszowskiej początkiem istotnych zmian. Zamiast dalej nienawidzić Wokulskiego, bohaterka docenia jego postawę; zamiast planowanej zemsty baronowa szczerze przeprasza Stawską i jej matkę. Wszystko wskazuje na to, iż Wirski ma rację, twierdząc:

To kobieta skruszona, żałuje za grzechy i niezawodnie poprawi się. [II 425]

\section{Baron i baronowa Krzeszowscy}

Konflikty, w jakie nieustannie popadają oboje Krzeszowscy, są efektem ich wzajemnej relacji, która polega na otwartej lub ukrytej walce toczonej przez 2 lata w warunkach nieoficjalnej separacji. Siła tego antagonizmu została zaznaczona pośrednio za pomocą zabiegów unifikujących. Ich występowanie w tego typu sytuacjach Girard wyjaśnia następująco:

Skandal jest relacją mającą równie złe konsekwencje dla osoby, która go wywołuje, jak i dla tej, która mu się poddaje. Skandal jest zawsze relacją sobowtórów, a różnica między oso-

33 Jak bowiem zauważa R. G i r a r d (Kozioł ofiarny. Przeł. M. G o s z c z y ń s k a. Łódź 1987, s. 195): „Dziecko bierze za przykład przede wszystkim najbliższego z dorosłych. Skoro zetknie się $\mathrm{z}$ osobą już wciągniętą w skandal, tak pochłoniętą pożądliwością, że jest już w niej hermetycznie zamknięta, to jej zamknięcie obierze za model dla siebie. Stanie się mimetyczną reprodukcją takiej postawy, jej groteskową karykaturą". 
bą prowokującą skandal a osobą ulegającą mu zawsze będzie miała tendencję do zaniku; bierny obiekt skandalu staje się jego wykonawcą, przyczyniając się do jego zatarcia ${ }^{34}$.

Tym, który rozpoczął konflikt, jest niewątpliwie baron, zazdrosny o pieniądze żony, nie pozwalającej mu z nich korzystać. Wiedząc, że ich intercyza wymaga obustronnego porozumienia, demonstracyjnie zrywa on małżeństwo i skutecznie blokuje fundusze baronowej, która zmuszona jest zaciągać pożyczkę na - ratujący ją od ostatecznej ruiny - zakup kamienicy (I 512-513).

Każda ze stron stanowi skuteczną przeszkodę w urzeczywistnieniu zamierzeń swojego adwersarza, ale nie oznacza to, iż sytuacja taka jest nienaruszalna. Antagonistom wydaje się bowiem, że potrafią zmienić - z korzyścią dla siebie - ten układ, dokonując różnorakich działań, prowokacji czy intryg. I właśnie takie zachowania znakomicie pokazują, iż wciągnięta w konflikt baronowa zaczyna upodabniać się do swojego męża. Wzajemna symetria małżonków jest w Lalce prezentowana $\mathrm{z}$ matematyczną wręcz precyzją: oboje w tym samym momencie dokonują zakupów w sklepie galanteryjnym, ukradkiem zerkając na siebie i oceniając efekt swych działań; oboje starają się dowiedzieć czegoś o sobie od Wokulskiego i - również oboje - wstawiają się u niego za Mraczewskim. Nawet różnica majątkowa okazuje się w praktyce niestabilna, gdyż autentyczne - tj. wynikające z rozrzutności - ubóstwo barona harmonizuje ze skromnym (wręcz skąpym) stylem życia baronowej, która także ma tylko jedną służącą i jada posiłki w podobnie niezdrowy sposób. Oboje nękani są przez analogiczne obsesje związane z pochodzeniem (baron nienawidzi mieszczaństwa, a baronowa - arystokracji), ale przede wszystkim - ze śmiercią. Oboje też potrafią teatralizować tę drugą fiksację, używając jej do swoich celów: baronowi śni się jego własny pogrzeb, dzięki któremu „okrada" żonę; baronowa w obliczu potencjalnej eksmisji rozpacza po stracie dziecka. Nic zatem dziwnego, że ich wygląd zewnętrzny także zmierza do ujednolicenia, gdyż oboje są równie zniszczeni i przedwcześnie postarzali.

Naturę ich relacji podsumowuje Mraczewski, stwierdzając:

Otóż pan baron i pani baronowa od roku prowadzą ze sobą wojnę. On chce rozwodu, na co ona się nie zgadza; ona chce przepędzić go od zarządu swoim majątkiem, na co on się nie zgadza. Ona nie pozwala mu trzymać koni, szczególnie jednego wyścigowca; a on nie pozwala jej kupić kamienicy po Łęckich, w której pani Krzeszowska mieszka i gdzie straciła córkę. Oryginały!... Bawią ludzi, wymyślając jedno na drugie... [I 187]

Istotnie, w ich zachowaniu znajduje się niemało groteskowego komizmu, ale ukryty jest w nim także konflikt, którego symetria sugeruje nienawiść graniczącą z opętaniem. Atak i kontratak następują po sobie z niezawodną precyzją, a każdy pretekst okazuje się doskonały do ich zrealizowania. Jeśli więc Lisiecki wcześniej określa ich mianem „,oryginalnych diabłów” (I 187), to nie jest to termin retoryczny: ich wzajemne zgorszenie prowadzi do niespotykanej eskalacji napięcia, które grozi obustronnym unicestwieniem.

Wokulski początkowo nie angażuje się w tę sytuację, zachowując neutralny dystans. Ale zachęcony przez panią Meliton, wkracza w ów spór i nabywa od

${ }^{34}$ R. G i r a rd, Things Hidden Since the Foundation of the World. Research undertaken in collaboration with J.-M. O u gh ourli an and G. Le fort. Transl. S. B an n and M. Mett e e r. Stanford 1978, s. 418. 
Krzeszowskiej klacz. Gdyby tego nie zrobił, hrabinie Karolowej i prezesowej Zasławskiej, oczywiście, udałoby się pogodzić małżonków, ponieważ baronowa jako pierwsza poczyniła pewne ustępstwa, które baron - dzięki odpowiedniej perswazji - powinien był docenić, zwłaszcza że mógłby na tym zyskać i pieniądze, i klacz. Wokulski jest jednak po stronie Izabeli, dlatego nic i nikt nie zdoła powstrzymać go przed zakupem, a potem przed wykorzystaniem owego „wyścigowca”.

Później, kiedy bohater wstępnie pogodził się z baronem, omal nie doprowadził do zaostrzenia niezgody, próbując udzielić mu finansowej pomocy. Skutecznie powstrzymał go Maruszewicz, który zresztą - szukając kolejnych źródeł pieniędzy - doprowadzi też (razem z adwokatem) do zawarcia transakcji między Wokulskim a Krzeszowską. Dopiero kupienie przez nią upragnionej kamienicy uzupełni pierwszy warunek - tj. brak kredytu dla barona - umożliwiający szukanie obustronnego pojednania.

Baronowa szybko bowiem przekona się, że prowadzenie takiego przedsięwzięcia przekracza jej kompetencje. Nie przewidziała zwłaszcza tego, iż postępując dość brutalnie z lokatorami, spotka się z odwetem, którego sprawcami okazują się studenci. Po ich eksmisji Krzeszowska jest już pewna, że sama nie potrafi rządzić kamienicą, w której czekają na nią wyłącznie śmiertelne zagrożenia (II 424). Uświadomienie ich sobie wywołuje najpierw zmianę nastawienia właścicielki do najemców (i swoich pracowników), a następnie zgodę na warunki, jakie bez wątpienia za pośrednictwem księcia postawił Krzeszowski.

Motywacją pojednania w obu przypadkach było doświadczenie zagrożenia: utraty życia przez baronową, a honoru nazwiska - przez zadłużonego barona. Jednakże, kiedy po raz ostatni małżonkowie wzajemnie się oskarżają, każde z nich przyznaje się do swoich przewinień i - między wierszami - prosi o wybaczenie (II 497-498). Wydaje się, iż potwierdzeniem jego uzyskania (dla obu stron) jest propozycja opieki barona, której baronowa nie tylko nie odrzuca, ale wręcz się domaga.

Postępowanie Wokulskiego przyrównane zostało w Lalce do przesiewającego ,przetaka” i pracującego ,anioła”. Jeśli ma ono pozostać funkcjonalne, należałoby odwrócić kolejność metafor ewangelicznych: dla tych, którym spełniają się błogosławieństwa (Wysoccy, Węgiełek), bohater jest „posłańcem” przynoszącym odpowiednią pomoc; natomiast wobec tych, których uwalnia od zgorszenia (Krzeszowscy), jest biernym „,narzędziem”, działającym niekiedy wbrew własnej woli. Pomiędzy tymi sferami znajdują się relacje Wokulskiego z ,jawnogrzesznicami", którymi opiekuje się zarówno z niechęcią (Maria), jak i zaangażowaniem (Stawska).

Postępując $\mathrm{w}$ ten sposób, protagonista - zgodnie z nowoczesną wykładnią przypowieści ewangelicznej - sprawia, iż owe „płacz i zgrzytanie zębów” powoli znikają z tej rzeczywistości. Wokulski czyni bowiem wiele, aby ustały cierpienie oraz walki, które, jak się okazuje, determinują czy zniekształcają egzystencję.

Wszelako działania tego bohatera bywają nieskuteczne: gdyż spośród osób, którym okazuje swoje zainteresowanie, niewiele potrafi z niego skorzystać. Prus precyzyjnie prezentuje ów paradoks ludzkiej wolności, tworząc postacie pozostające bliźniaczymi odbiciami tych, o których była tu mowa. Wokulski pomaga bowiem nędzarzowi, którym początkowo jest - osamotniony, pozostający w kon- 
flikcie z ojcem - młody Szlangbaum; swojego służącego Pawła traktuje sprawiedliwie, obdarzając go dodatkowymi gratyfikacjami; a zagrożony sklep nieporadnej wdowy po Millerze chroni przed katastrofą. A jednak - żadna z tych postaci nie osiągnie tego, co zapowiadają błogosławieństwa. ,Smutny” Szlangbaum niedługo stanie się dumnym, podatnym na konflikty i rywalizację przedsiębiorcą; ,,spragniony sprawiedliwości” Paweł obraża niemal wszystkich, którzy przychodzą do domu Wokulskiego (zwłaszcza Obermana i Węgiełka), a ,cicha” Millerowa zacznie ukradkiem dręczyć panią Stawską.

Nie znikają również zgorszenia: Maruszewicz, któremu protagonista darował popełnione oszustwo, oszustem pozostanie, stale wyłudzając pieniądze potrzebne do uprawiania hazardu. Studenci, którym Wokulski ufundował stypendia, a Krzeszowski ponownie zapewnił mieszkanie na poddaszu, będą teraz z analogiczną pasją i pomysłowością prześladować Maruszewicza. Ten, niestety, w ramach odwetu sprowadzi na spiskującą młodzież policję carską.

Żadna z tych postaci nie skorzystała z szansy, jaką stworzył dla nich Wokulski. Dlatego ,płacz i zgrzytanie zębów” stanie się ich udziałem, nawet jeśli Lalka zatrzyma się przed prezentacją tych zjawisk. Prus prawdopodobnie uznał, iż nie jest oczywiste, czy dokona się to na tym, czy na tamtym świecie.

\section{Akty cytowania}

Istnieje w Lalce szereg biblijnych cytatów, których funkcjonalizacja wyraźnie zawęża się do aktu przytoczenia, jakiego albo dokonują bezpośrednio bohaterowie, albo, rzadziej, wyręcza ich w tym narrator. Niezależnie jednak od tego, jaka instancja nadawcza jest wykonawcą tego zabiegu, jego intencja zawsze kończy się przywołaniem autorytetu. Dlatego cytujący dosłownie - i niemal dokładnie - biblijne frazy, podkreślają zarówno źródło, z jakiego je zaczerpnęli, jak też własny do nich stosunek, który sprowadza się do pełnej akceptacji przekazu.

Paradoks tego zjawiska polega jednak na tym, iż ów akt jest zarazem formą (auto)charakterystyki postaci. Dlatego każda z nich, dokonując afirmatywnego przytoczenia Biblii, równocześnie sugeruje swoją - i sobie tylko właściwą - interpretację danego fragmentu. Jest ona wynikiem całego szeregu okoliczności, spośród których dominującą rolę odgrywa osobowość bohatera oraz jego aktualna sytuacja egzystencjalna. Trudno się zatem oprzeć wrażeniu, iż panna Izabela (I 96, 134), baron Dalski (II 237) ${ }^{35}$ czy Ignacy Rzecki (II 53) subiektywizują te passusy, przystosowując je do własnej sytuacji.

Wydaje się zatem, iż Prus dokonał wyraźnego podziału między postaciami, które przywołują Biblię. Wymienieni właśnie bohaterowie cytują w sposób zarazem bezpośredni, lecz też skażony, nadmiernie zindywidualizowany. Natomiast Stanisław Wokulski oraz Kacper Wysocki, wykorzystując Biblię, postępują dokładnie odwrotnie: cytują pośrednio (za pomocą istniejących już parafraz), ale za to adekwatnie, bez nadmiernych idiosynkratycznych zniekształceń.

35 W przypadku Dalskiego trafna pozostaje obserwacja E. P a c z o s k i e j (Lalka czyli rozpad świata. Białystok 1995, s. 124), która stwierdza, iż biblijna wizja raju, jaką sugeruje on za pomocą cytatu, przypomina: „obraz nieba, gdzie starcza seksualność barona znajdzie normalne zaspokojenie!” 
Spacer na Powiślu

Wychodząc ze sklepu, Wokulski jest przekonany, że jego miłość do Izabeli skończyła się nieodwołalnie ${ }^{36}$. Kolejnym dowodem potwierdzającym taką intuicję jest - jedna z pierwszych - obserwacja bohatera, który dostrzega ubogiego tragarza korzystającego z miejskiego wodotrysku. Wokulski zastanawia się nad jego zadowoleniem:

Jużci, ten ma, czego pragnął. Ja, ledwiem zbliżył się do źródła, widzę, że nie tylko ono znikło, ale nawet wysychają moje pragnienia. Pomimo to mnie zazdroszczą, a nad nim kazali się litować. Co za nieporozumienie! [I 156]

Prus wprowadza tu ,pragnienie" na prawach homonimu: dla robotnika oznacza ono naturalną potrzebę, a dla Stanisława miłość. Różnica między tymi zjawiskami staje się najlepiej - i w sposób maksymalnie kontrastowy - widoczna, kiedy dochodzi do ich spełnienia. Tragarz odczuwa wówczas spontaniczną satysfakcję, natomiast Wokulski - już po pierwszym spotkaniu z Izabelą - doznaje przejmującej pustki ${ }^{37}$. Jego doświadczenia przebiegają niemal symultanicznie, ale wypowiedź sugeruje ich strukturę przyczynowo-skutkową: zniknięcie dotychczasowego „celu” pozbawia bohatera wewnętrznej motywacji. Wniosek, jaki przez zaprzeczenie można by z tej obserwacji wyciągnąć, brzmiałby: pragnienie trwa dopóty, dopóki jego „obiekt” jest niedostępny, nieosiągalny.

Natychmiastowym efektem wygaszenia podstawowego pragnienia jest, jak stwierdza Wokulski, apatia, wyczerpanie (I 153), czyli nuda. Nic i nikt go już nie interesuje: ani sklep, ani zatrudnieni ludzie, ani - zwłaszcza - przyszły kształt własnej egzystencji.

W takim kontekście Prus wprowadza do rozmyślań protagonisty cytaty z Króla Salomona Włodzimierza Zagórskiego, a więc z utworu, który parafrazuje biblijną Księgę Koheleta oraz Pieśń nad Pieśniami. Znamienny jest jednak wybór fragmentów, który koncentruje się wyłącznie na pierwszym źródle, pomijając zawartą w drugim apoteozę miłości ${ }^{38}$. Powstaje zatem silna, intertekstualna sugestia, iż zasadniczy temat Księgi Koheleta - słynna „marność” - jest powiązany zarówno z problemem radykalnego zaniku pragnienia, jak i z następującą po nim nudą.

Przekonujące wyjaśnienie tych relacji przedstawił współczesny myśliciel Jean-Luc Marion w filozoficzno-teologicznej pracy pt. Bóg bez bycia. Nuda powstaje w wyniku negacji idola, która pozbawia go godności (M 163-164). Takim idolem, wobec którego Wokulski odprawia bałwochwalczy kult, jest panna Izabela. Dla-

${ }^{36}$ Szerzej piszę o tej kwestii w książce Powracająca fala (s. 187-188).

${ }^{37} \mathrm{Nb}$. istnieje niejakie pokrewieństwo tej sceny z pewnym epizodem, który znajduje się w - znanych Prusowi - Wyznaniach św. A u gu styna (Przeł., wstępem i kalendarium opatrzył Z. K u b i a k. Warszawa 1992, s. 158). Ich bohater, spacerując ulicami Mediolanu, także spotyka zadowolonego z niedawno otrzymanej jałmużny żebraka. W zestawieniu z nim święty odczuwa jednak nie pustkę, ale cierpienie wynikające z tego, iż on jeszcze nie wyzbył się własnych pragnień: „Moje ambicje obarczyły mnie brzemieniem, które stawało się tym cięższe, im dalej je niosłem, a przecież wszystkie te wysiłki miały tylko jeden cel: osiągnięcie spokojnego szczęścia. I oto ten żebrak już nas w tym wyprzedził, a my do celu może nigdy nie dojdziemy. To, do czego ja dążyłem przez tyle mozolnych, krętych zabiegów, on osiągnął za garść użebranych monet - radość ziemskiego szczęścia”. Zob. też H. I 1 m u r z y ń s k a, A. S t e p n o w s k a, Księgozbiór Bolesława Prusa. Warszawa 1965, s. 51.

${ }^{38}$ Zob. P a c zos k a,op. cit., s. 113-114. 
tego znudzenie, w jakim nieoczekiwanie znajdzie się protagonista spacerując po Powiślu, byłoby niemożliwe, gdyby Łęcka sama nie zniweczyła swojej pozycji w trakcie niedawnego pobytu w sklepie. Nie jest już ona idolem, ale banalną kobietą, wobec której pragnienie Wokulskiego znika tak szybko, jak się pojawiło. Marion jest przekonany, że:

Nuda narzuca temu, co widzi, nie unicestwienie, lecz brak różnicy pomiędzy statusem bytu i niebytu. Zawieszenie znudzonego spojrzenia wykorzenia przedstawiający się spojrzeniu widok z Bycia. Takie wykorzenienie można określić mianem marności. Znudzone spojrzenie poraża byt w ogóle marnością. [M 170]

Ten właśnie brak dystynkcji między podstawowymi kategoriami Marion analizuje dokładniej, sięgając po Księgę Koheleta, w której tak rozumiane doświadczenie marności znalazło najpełniejszą ekspresję. Filozof rozpoczyna od jego zewnętrznej charakterystyki, która obejmuje trzy podstawowe cechy. Pierwsza dotyczy zakresu:

To, czego dotyka omawiana marność, nie ma granic. Marność przenika „wszystko”. Inaczej mówiąc, nic jej się nie wymknie, jak to wkrótce powie inny werset: „Nic zgoła nowego nie ma pod słońcem" (Koh 1,9). [...] Zatem wszystko, co nowe - a bez przerwy pojawia się z biegiem dni i lat - nie przynosi tak naprawdę żadnej nowości. Ogólną całość rzeczy należy więc pojmować nie tylko przestrzennie, ale przede wszystkim czasowo. Chodzi, oczywiście, o wszystko w niemożliwym empirycznie, ale rzeczywistym w oczach jakiejś świadomości zsumowaniu. Tutaj powiemy: w oczach znudzonego spojrzenia; dokładniej - w znudzonym spojrzeniu. [M 171]

Kiedy zatem w refleksjach Wokulskiego pojawia się pierwszy cytat koncentrujący wanitatywną problematykę wokół kwestii temporalnych, należałoby umieścić go w kontekście poczynionych tu analiz. Przywołany (i lekko zniekształcony) fragment z Zagórskiego jest następujący:

Mijają ludzkie pokolenia

Jak fale, gdy wiatr morzem zmęci;

I nie masz godów ich pamięci,

I nie masz bólów ich wspomnienia. [cyt. z: I 154]

Poeta prawdopodobnie odsyła tu do początkowych wersetów księgi, wedle których:

Pokolenie przychodzi i pokolenie odchodzi,

a ziemia trwa po wszystkie czasy. [Koh 1, 4]

Zagórski - za Koheletem - eksponuje przemijanie kolejnych generacji, podkreślając przy tym brak jakiegokolwiek dziedzictwa, które niezmiennie (niczym natura) świadczyłyby o ich istnieniu. Marność polega więc na tym, iż dorobek następujących po sobie formacji nie kumuluje się, ale, przeciwnie, znika wraz z nimi. Marion wyjaśniłby ten proces założeniem, zgodnie z którym każde pokolenie jedynie powiela to, co osiągnęło poprzednie. Wszyscy powtarzają to samo, dlatego w efekcie nie powstaje ani nic nowego, ani trwałego ${ }^{39}$.

${ }^{39}$ Przejście od braku innowacji do nietrwałości (i odwrotnie) jest także implikowane przez W. Z a g ó r s k i e g o (Król Salomon. Poemat liryczny w trzech pieśniach. Warszawa 1887, s. 26), który zacytowaną przez Prusa zwrotkę poprzedził następującą:

Znikomość jest dzieł ludzkich gońcem:

Co jest - to było już od wieka, 
W rozważaniach Wokulskiego pojawia się motyw analogiczny, dotyczący tego typu sukcesji, jakie dokonują się w całym społeczeństwie:

Oto miniatura kraju - myślał - w którym wszystko zmierza do spodlenia i wytępienia rasy. Jedni giną z niedostatku, drudzy z rozpusty. Praca odejmuje sobie od ust, ażeby karmić niedołęgów; miłosierdzie hoduje bezczelnych próżniaków, a ubóstwo, nie mogące zdobyć się na sprzęty, otacza się wiecznie głodnymi dziećmi, których największą zaletą jest wczesna śmierć. [I 158]

Postęp jest paraliżowany przez marazm, w którym wszyscy tkwią i który uniemożliwia doskonalenie. Następujące po sobie generacje jedynie akceptują zastany porządek, niezależnie od tego, czy jego istotą jest skrajna nędza czy równie nieograniczony dobrobyt. Nic nowego, a nawet - i tu pesymizm protagonisty jest silniejszy - rzeczywistość nieuchronnie dąży do degeneracji, rozpadu.

Drugą wyróżnioną przez Mariona kwalifikacją marności jest ontologiczna unifikacja, która wszystkiemu odbiera status bytu. Jest to podstawowa, a zarazem nieoczywista funkcja, ponieważ:

w świecie wielką widać jednak różnicę pomiędzy tym, że można żyć i już nie żyć, cieszyć się i cierpieć, mieć i nie mieć, wiedzieć i błądzić, a nawet [...] być i nie być. Takie zróżnicowanie nie ma w sobie nic pozornego i posiada wszelkie znamiona rzeczywistości, o k r eślo n e j rzeczywistości. Marność może zawiesić to zróżnicowanie [...]. [M 173]

Prus każąc Wokulskiemu rozważać okoliczności utraty życia, wybiera najbardziej egzystencjalną i dramatyczną wersję tego doświadczenia. Dystynkcja między własnym istnieniem a jego brakiem zostaje zanegowana, gdyż protagonista przyznaje, iż w sytuacji napadu nie broniłby się przed napastnikami. Znika zresztą także różnica między „mordercami” a „dobroczyńcami”, jak i między „grobem” a ,śmietnikiem” (I 175).

Uzasadnieniem tego doświadczenia jest przywołany fragment Króla Salomona:

$\mathrm{O}$, bo nie znają, w snach mogilnych

Drzemiący, ciężkich trosk żywota

I duch się ich już nie szamota

W pragnieniach - tęsknych a bezsilnych... [cyt. z: I 175]

Inspiracją był tu zapewne biblijny werset:

Więc za szczęśliwych uznałem umarłych, którzy dawno już odeszli, od żyjących, których życie jeszcze trwa. [Koh 4, 2]

Zatem geneza zawieszenia dokonywanego przez marność znajduje się w ocenie, jakiej podlega dana rzeczywistość. Jeśli diagnoza jest negatywna - a zawsze taka jest - wówczas nieistnienie okazuje się stanem preferowanym, pozytywnym. Prus znowu radykalizuje tę sytuację, ponieważ owo rozpoznanie polega nie tyle na stwierdzeniu bezsilności pragnienia, ile na jego wyczerpaniu. Dlatego kiedy Wokulski będzie oglądał nieruchomy statek na Wiśle, a następnie przypomni sobie analogiczne wydarzenie z Bułgarii, to ponownie potwierdzi ,zatrzymanie” swojej miłości: dręczącą go pustkę po wygasłym uczuciu (I 176-177).

Trzeci wyznacznik marności to obojętność. Wynika ona z poprzedniej kwalifikacji, gdyż, jak wyjaśnia Marion, jest jej zastosowaniem w obrębie specyficznie ludzkiej działalności, jaką stanowi praca. Z perspektywy marności: 
nic nie jest ważne. To, że człowiek pracuje, nie robi żadnej różnicy, albo raczej różnica, jaką praca ustanawia wśród rzeczy z uwagi na korzystny interes, nic już nie znaczy [...]; korzystny interes nie interesuje wcale człowieka [...], skoro marność czyni obojętnym wszelkie właściwe światu oraz istniejące w jego wnętrzu zróżnicowanie. [M 174-175]

Wokulski powtarza więc za Zagórskim deklarację indyferencji względem twórczych wysiłków:

I cóż ma $\mathrm{z}$ trudu swego człowiek?...

I z prac tych, które wszczął pod słońcem?...

Znikomość - jego dzieła gońcem,

A żywot jego mgnieniem powiek. [cyt. z: I 157]

Poeta parafrazuje tu kluczowy werset, który otwiera Ksiege Koheleta:

Cóż przyjdzie człowiekowi z całego trudu,

jaki zadaje sobie pod słońcem? [Koh 1,3]

Zgodnie z tym przesłaniem Wokulski nie tylko kwestionuje projekt wybudowania bulwarów nad Wisłą (I 156), ale wręcz zaciera różnicę między tym zamierzeniem a aktualnym stanem Powiśla. Z perspektywy historycznej nawet najwspanialsze dokonania okazują się skazane na zagładę i rozkład, które już ,teraz” bohater zapamiętale kontempluje, dokonując inspekcji nadwiślańskich slumsów (I 157-158).

Kiedy Marion przechodzi do określenia natury marności, stwierdza, iż sprowadza się ona do niestabilności, pewnej ulotności. Konkretyzacja tej tezy nie bez powodu odbywa się na poziomie antropologicznym: człowieka ujmuje się bowiem jako istotę podatną na wszelkiego typu zmiany. Precyzując to przekonanie, autor konkluduje:

Ale „marność” człowieka nie polega na tego rodzaju kolejnych przemianach (gdzie w grę wchodzi tylko zwykła przypadkowość czegoś skończonego). Nie polega ona również na zupełnej zewnętrzności tchnienia, które wywołuje kolejne przemiany (gdzie w grę mogłaby wchodzić tylko dominacja). Polega ona na tym, że absolutnie zewnętrzne przemiany nie niszczą całkowicie ani nie unicestwiają, lecz tylko rozpraszają, rozwiązują, burzą. [M 178-179]

Marność nie jest więc ani tradycyjną incydentalnością egzystencji, ani jej mechanicznym uzależnieniem od czegokolwiek; jest natomiast wrażliwością na wewnętrzne procesy dyspersji czy częściowego zanikania, które nigdy nie osiągają stanu maksymalnej anihilacji.

Dodanie do powieściowej psychologii tych abstrakcyjnych tez prowadzi do wniosku o nietrwałej, zjawiskowej naturze pragnienia. Ale, i to jest niezwykle ważne, owa ulotność funkcjonuje w obu wymiarach: rozpraszania i konsolidacji czy burzenia i budowania. Marion tej drugiej ewentualności nie rozważa, natomiast Prus kładzie na nią nacisk, przedstawiając metamorfozę spacerującego Wokulskiego $^{40}$. Kiedy bowiem dyspersja jego uczucia okaże się niemal zupełna, wówczas

${ }^{40}$ Znamienny jest fakt, iż analogiczne zjawisko pojawia się także w dyskursie kronikarskim. W roku 1886, zachwalając Króla Salomona, Pr u s (Kroniki, t. 9 〈1960〉, s. 134-135) dostrzega w tym utworze przede wszystkim apoteozę marności: „świat nasz, w którym wszystko znikome, z prochu powstaje i w proch się obraca, wszystko - zacząwszy od człowieka i ludzkich pokoleń, aż do rzek, oceanów i gwiazd". Natomiast w r. 1888, kiedy wykorzystywał (niemal identyczne jak w Lalce) fragmenty tego poematu w kronice pisanej tuż po Zaduszkach, snuł na ich podstawie refleksje dotyczące wiecznych, nieprzemijających aspektów działalności człowieka, które również - 
równie nieoczekiwanie nastąpi odnowienie miłości, z której nie będzie on w stanie zrezygnować (I 178). Mechanizm ten jest zresztą lustrzanym odbiciem poprzedniego, dlatego zostaje poprzedzony stopniową rezygnacją z nudy.

Protagonista trzykrotnie wyrzeka się zatem perspektywy wanitatywnej: doskonalenie kolejnych generacji jest możliwe, i to nie tylko w Anglii (I 177-178), ale i w Polsce - dzięki potomstwu Stanisława i Izabeli (I 175); praca okazuje się wartością trwałą, niepodważalną, służącą wzrostowi społeczeństwa (I 176), a wykonane dzięki niej bulwary i kanalizacja zlikwidują wysoką śmiertelność oraz śmietnik w środku miasta (I 172). Wszystkie te projekty nie tylko usuwają nudę, lecz przygotowują kolejną intronizację niedawno zdegradowanego idola - Izabeli.

\section{Sytuacja w Skierniewicach}

Niejednokrotnie podkreślano już ścisły związek, jaki zachodzi między scenami na Powiślu i w Skierniewicach. Warto jeszcze wskazać na jedną z pierwszych medytacji Wokulskiego, która zawiera intrygujący obraz lokomotywy:

Szczególna rzecz - mówił. - Każdy ptak w górze i każdy człowiek na ziemi wyobraża sobie, że idzie tam, dokąd chce. I dopiero ktoś stojący na boku widzi, że wszystkich razem pcha naprzód jakiś fatalny prąd, mocniejszy od ich przewidywań i pragnień. Może nawet ten sam, który unosi smugę iskier, wydmuchniętych przez lokomotywę podczas nocy?... Błyszczą przez mgnienie oka, aby zgasnąć na całą wieczność, i to nazywa się życiem. [I 154]

Rozważania te zdecydowanie są inne od refleksji, jakie protagonista snuł spacerując nadwiślańskim wybrzeżem. Definicja marności, którą zaproponował Marion, pozwala precyzyjnie określić tę różnicę: wedle Wokulskiego kondycja ludzka polega tu właśnie na fatalistycznym determinizmie oraz na nietrwałości, ulotności. Taka koncepcja wydaje się łudząco podobna do tej, jaką zawiera Księga Koheleta, niemniej - ta analogia jest fałszywa. Bohater ulega więc tu skrajnemu pesymizmowi, który z perspektywą biblijną nie ma nic wspólnego, chyba że na zasadzie zaprzeczenia ${ }^{41}$.

podobnie jak w powieści - koncentrują się wokół pracy, wysiłków cywilizacyjnych czy doskonalenia upośledzonych warstw społecznych (P r u s, Kroniki, t. 11〈1961〉, s. 224-226).

41 Jeśli bowiem rację ma To k a r z ó w n a (op. cit., s. 41) twierdząc, iż fragment ów zawiera kryptocytat z Księgi Hioba (Hi 5, 5), to należy dodać, że wypowiada go jeden z oskarżycieli tej postaci biblijnej, Elifaz. To zaszyfrowane przytoczenie można więc uznać za rodzaj kuszenia, jeśli przyjmie się, iż w Nowym Testamencie szatan oznacza właśnie „oskarżyciela”. Przy takiej interpretacji warto wskazać na kolejną klamrę między analizowanymi fragmentami: kwestia oddziaływania złego ducha pojawi się bowiem explicite, kiedy Wokulski będzie przebywał jeszcze na stacji w Skierniewicach. Słysząc ryk pociągu, przypomina sobie arię z Roberta Diabła (II 522-523), w której demoniczny Bertram wzywa do posłuszeństwa. Analogia ta jest niezwykle precyzyjna, ponieważ zarówno Elifaz (i jego sprzymierzeńcy), jak też Bertram nie uzyskują zwycięstwa nad Bogiem w zmaganiach o dusze bohaterów. $N b$. w przypadku Roberta Diabła była to zasługa polskich thumaczy - na których wersji opierał się Prus - sprawiających, że „Ów wcielony w ludzką postać szatan objawił się w polskim libretcie opery jako istota przebiegła i aktywna, ale wobec potęgi niebios całkowicie bezwładna. W toku walki o duszę Roberta »polski« Bertram nie prezentuje pewności siebie, jaka charakteryzuje jego francuski pierwowzór. Deklaracje Bertrama, dowodzące jego wiary w ostateczne zwycięstwo, pojawiają się we francuskim libretcie kilkakrotnie - w polskim tekście zostały one konsekwentnie przez thumacza usunięte" (A. B o r k o w s k a - R y c h $1 \mathrm{e}$ w s k a, Literackie metamorfozy ,Roberta Diabla”. O polskich wersjach libretta opery Giacoma Meyerbeera i dramatu Ernsta Raupacha. „Pamiętnik Literacki” 2004, z. 1, s. 105). 
Fragment ten dlatego jest ważny, iż dostarcza scenariusza, zgodnie z którym będzie - przynajmniej do pewnego momentu - postępował Wokulski w Skierniewicach. Widząc bowiem ów wyrzucany przez lokomotywę „snop iskier” (II 528), niemal mechanicznie rezygnuje z powziętej decyzji powrotu do Warszawy i zbliża się do torów, szukając jedynie śmierci. Natomiast kiedy minie zagrożenie fizycznego unicestwienia, Wokulski ponownie znajdzie się na krawędzi istnienia: będzie rozpaczał za utraconym bezpowrotnie szczęściem, które okazało się przemijające (II 529-530).

Jeśli zatem ów fatalizm i owo doświadczenie nietrwałości nie doprowadziły ostatecznie protagonisty do nicości (fizycznej i moralnej), to jest w tym zasługa nie tylko dróżnika Wysockiego. Wokulski za każdym razem odwołuje się tu do Boskiego miłosierdzia ${ }^{42}$ - i wezwanie to nie pozostanie bez echa.

Wysocki postępuje adekwatnie do sytuacji: najpierw ściąga Wokulskiego z torów, a następnie pomaga mu odzyskać spokój wewnętrzny. Słysząc drugie wezwanie (i towarzyszący mu płacz), potwierdza jego sens i, jakby w odpowiedzi, cytuje Psalm 91:

- Płacz wielmożny panie, i wzywaj boskiego imienia... Nie będziesz go wzywał nadaremnie... „Kto się w opiekę poda Panu swemu, a całym sercem szczerze ufa jemu, śmiele rzec może: mam obrońcę Boga, nie spadnie na mnie żadna straszna trwoga... Ciebie on z sideł zdradzieckich wyzuje..." Co tam, wielmożny Panie, dostatki, co największe skarby!... Wszystko człowieka zawodzi, tylko jeden Bóg nie zawiedzie... [II 530-531]

Tłumaczenie współczesne (pomijające wersję Jana Kochanowskiego) brzmi następująco:

Kto przebywa w pieczy Najwyższego
i w cieniu Wszechmocnego mieszka,
mówi do Pana: „Ucieczko moja i Twierdzo,
mój Boże, któremu ufam”.
Bo On sam cię wyzwoli
z sideł myśliwego [...]. [Ps 91, 1-3a]

Tokarzówna wskazuje, że przekład, jakiego używa Wysocki, pochodził prawdopodobnie z modlitewnika ludowego ${ }^{43}$. Jeśli tak, to nader znamienna jest długość tego passusu, która nie mogła wynikać z luk pamięciowych, skoro dróżnik posługiwał się wersją dobrze znaną i przyswojoną. Sądzę zatem, iż to niespodziewane zakończenie, które ignoruje nawet porządek składniowy psalmu, służy, po pierwsze, wyraźnej koncentracji wokół jego pierwszych trzech (niepełnych) wersetów, a także - po drugie - pozwala zaakcentować własny komentarz, jakim uzupełnia ten cytat Wysocki.

Jego słowa nawiązują do tego doświadczenia, jakie stało się udziałem protagonisty na Powiślu; wyrażają bowiem analogiczną triadę: znikomość, zrównanie wszystkiego, obojętność. Jednakże owa marność nie jest - już - wyłączna, gdyż jej dopełnieniem i zarazem przekroczeniem okazuje się Bóg ${ }^{44}$. Pod tym względem

${ }^{42}$ Zob. O b sulewicz-Niew ińska, op. cit., s. 466-467.

${ }^{43}$ To karzówn a, op. cit., s. 43.

${ }^{44} \mathrm{M}$ a r i o n (M 185) jest przekonany, iż taka jest istota biblijnej marności: „rodzi się [ona] ze spojrzenia, które wychodzi poza Bycie/byt, nie dochodząc jeszcze do miłości, które odkrywa będący poza Byciem/bytem świat, nie wiedząc, że świat jest kochany - przez Boga. Spojrzenie Koheleta - 
scena w Skierniewicach domyka nadwiślański spacer; a domknięcie to tym razem jest fortunne. Pierwsza bowiem próba, która pojawiła się niemal natychmiast w trakcie wielkopostnej kwesty, zakończyła się fiaskiem: ponieważ żadna przemiana religijna nie dokonała się wówczas w Wokulskim, podważającym nawet działanie miłosierdzia Boskiego (I 209).

W Skierniewicach bohater - w ataku desperacji, rozpaczy - odwołuje się właśnie do miłosierdzia i zostaje wysłuchany. Wysocki nie tylko go uratuje, ale do niego przemówi za pomocą biblijnego fragmentu, który teraz (inaczej niż w Wielką Sobotę) jest zarazem słyszany i rozumiany. Prus, dbając o prawdopodobieństwo psychologiczne, nie wprowadza tu medytacji, ale o tym, iż passus ten wywarł istotny wpływ, świadczy uspokojenie oraz równowaga Wokulskiego, jaką niedługo odzyskuje.

Pisarz nie dopowiada zatem interpretacji, dlatego warto, jak sądzę, zaryzykować hipotezę mogącą wyjaśnić sens, który okazał się tak funkcjonalny. Wydaje się, iż nader pomocna w tym względzie byłaby egzegeza Psalmu 91 dokonana przez św. Augustyna. Ostatni, ,urwany” werset teolog tłumaczy następująco:

Zastawia diabeł i jego aniołowie sidła, niczym łowcy. Ludzie wierzący w Chrystusa chodzą z dala od tych sideł. Przecież nie śmie na Chrystusa zastawić pułapki. Koło drogi, a nie na drodze, zastawia sidła. Niechaj twoją drogą będzie Chrystus, a nie wpadniesz w sidła diabelskie. Kto zejdzie z drogi, ten wpadnie już w sidła. Tu i tam zastawia pęta, tu i tam zakłada pułapki. Chodzisz pomiędzy sidłami. Chcesz bezpiecznie iść? Nie zbaczaj ani na prawo ani na lewo. I nich ci będzie drogą ten, który stał się dla ciebie drogą, i niechaj doprowadzi cię do siebie przez siebie, a nie ulękniesz się sideł łowców ${ }^{45}$.

Święty łączy separację od ,diabelskiej ścieżki” z pokorą:

A „kto mieszka w chronieniu Najwyższego?” Kto nie mieszka w swoim schronieniu. Kim jest ten „kto mieszka w schronieniu Najwyższego?” Kto nie jest pyszny jak ci, którzy jedli owoc, żeby stać się niczym bogowie. [s. 175]

Ten warunek jest jeszcze niewystarczający. Istota polega bowiem na odpowiednim postępowaniu:

Zatem ten, kto w taki sposób naśladuje Chrystusa, że znosić będzie wszelkie utrapienia życia obecnego i że zaufa Bogu, nie pozwoli usidlić się ponętom ani złamać strachem. On jest tym, ,kto mieszka w schronieniu Najwyższego i przebywać będzie pod osłoną Boga niebios” [...]. [s. 175]

Tradycyjna reguła imitatio Christi, która, jak dobitnie podkreśla św. Augustyn (s. 173-174), nie polega na dokładnym kopiowaniu, ale na odwzorowaniu pewnej postawy, gwarantuje bezpieczeństwo i ochronę przed ,trudnościami tego świata, które sprawia diabeł, czy to jawnie przez ludzi, czy też potajemnie [...]” (s. 174).

Ten komentarz ujmuje dotychczasowe perypetie Wokulskiego w perspektywie teologicznej. Kto pozostaje daleko od Boga, stale naraża się na pokusy idolatrii: na szukanie bóstw zastępczych. A kiedy proces ten się rozpocznie, wtedy sidła

i nasze - wkracza w dystans, nie przebiegając go i nie obsypując świata miłością, poraża go marnością. Marność wypływa ze znudzenia człowieka, a nie ze znudzenia Boga, bo Bóg kocha, a z pełnego miłości spojrzenia wynika »dobroć« oglądanego".

${ }_{45}$ Św. A u g u s ty n, Objaśnienia psalmów. Ps 78-102. Przeł., wstęp J. S u 1 k o w s k i. Oprac. E. S t a n u la. Warszawa 1986, s. 176. Dalej do tej pozycji odsyłam podając stronice w nawiasie. 
zaciskają się coraz szczelniej, tak iż trudno jest odzyskać utraconą wolność. Wokulskiemu się udało, chociaż nawet w momencie krytycznym w to nie wierzył, pozostając osaczony przez okrutną boginię i demonicznego rywala. Teraz, słuchając psalmu, przekonuje się, że ostateczne potępienie oddala się od niego niczym niknący na horyzoncie pociąg.

Między naśladowaniem ludzi a naśladowaniem Chrystusa różnica wydaje się niewielka; i dlatego św. Augustyn mówi o zasadzkach, które znajdują się tuż obok drogi, jaką podąża wierzący. Dzieje Wokulskiego, istotnie, świadczą o tym, jak łatwo można z niej zejść; ale też - że powrót na nią nie jest niemożliwy. Nie bez powodu zatem profesja braci Wysockich związana jest z drogą ${ }^{46}$ : pierwszy jedynie zapowiada, ale drugi potwierdza fakt oswobodzenia protagonisty ze ,zdradzieckich sideł", które znajdują się poza wytyczoną trasą.

\section{Wnioski}

Przedstawione w artykule analizy dowodzą, iż między passusami z Biblii a warstwą narracyjną Lalki zachodzą istotne powiązania. Ich określenie jest paralelne do techniki, za której pomocą zostają wprowadzone: tam, gdzie pojawiają się sygnalizowane cytaty, dominuje funkcja prefiguracyjna dotycząca rozwoju fabuły; natomiast tam, gdzie zasadniczą rolę odgrywają akty cytowania, występuje charakterystyka i autocharakterystyka (wewnętrzna) postaci.

Owa podwójna funkcjonalizacja jest tyleż oczywista, ile kłopotliwa. Niewątpliwie bowiem wskazuje na ważną rolę, jaką w Lalce odgrywają te związki intertekstualne, a zarazem podsuwają rozmaitą ich interpretację. Jeśli uznać, że „między tekstami" niekoniecznie zachodzi relacja dialogiczna ${ }^{47}$, to trzeba by przyjąć albo jednostronną supremację ${ }^{48}$, albo polifoniczną indyferencję $e^{49}$.

Gdyby wszakże założyć, że istnieje wspólna płaszczyzna między powieścią a biblijnymi passusami, to określenie owej więzi i tak pozostaje kłopotliwe. Kwestię tę nieco przybliża jeden z ostatnich tekstów Josepha Hillisa Millera. Kiedy ów teoretyk stara się - na poziomie nader abstrakcyjnym - opisać wzajemne relacje literatury i Biblii, dochodzi niemal wyłącznie do sceptycznych konkluzji. Pozwala sobie tylko na jedną, ryzykowną hipotezę:

Konwencja nieskrępowanej mowy pośredniej w narracji trzecioosobowej presuponuje całkowicie nieprawdopodobną przejrzystość umysłów bohaterów wobec jasnowidzącego narratora, co więcej, bohaterowie ukazani są jako nieświadomi faktu, iż narrator ich szpieguje. Literatura i Biblia mogą strzec swoich sekretów, ale równie hojnie - i, być może, nieodpowiedzialnie - zdradzają je. Czytelnik Księgi Rodzaju wie więcej, niż wiedzieli Sara i Izaak, więcej nawet, niż wiedział Abraham. Jeśli myślimy o Księdze Rodzaju jako o historii spisanej przez

46 Zob. O bs u lewicz-Niew ińska,op. cit., s. 460.

47 Zob. Martuszewska, op. cit., s. 78.

${ }^{48} \mathrm{~W}$ wieku XIX sytuacja taka nie była zresztą rzadka. Np. w literaturze zachodnioeuropejskiej operującej motywami biblijnymi niejednokrotnie pojawiało się założenie, zgodnie z którym: „Powieść [...] była ujmowana jako potężne narzędzie propagandy z tego właśnie powodu, że mogła przekazywać rzeczywiste odczucie świata, rozumianego w kategoriach katolickich, heretyckich lub sceptycznych; świata złożonego raczej z uczuć i doświadczeń niż z formuł abstrakcyjnych" (T. R. W r i g h t, Theology and Literature. Oxford 1988, s. 115).

49 Zob. M. G 1 o g e r, Determinizm w „Lalce” Bolestawa Prusa. „Pamiętnik Literacki” 2000, z. 2, s. 40 . 
Mojżesza pod dyktando Jehowy, dysponujemy wówczas sensownym wyjaśnieniem, dlaczego tekst zna wszystkie owe tajemnice. Jednakże wciąż pozostaje niezgłębionym sekretem, dlaczego Jehowa zdecydował się ją upublicznić, tak by każdy mógł je przeczytać, tajemnice, które, jeśli Derrida ma rację, pozostają sekretne wieczyście, zasłonięte przez milczenie Boga i przez milczenie Abrahama, które jest jego echem. Jezus obiecał swoim uczniom, objaśniając przypowieść o siewcy, iż poznają tajemnice Boga. Uczniowie pytali, „Dlaczego w przypowieściach mówisz do nich?”. Jezus odpowiedział: „Wam dano poznać tajemnice królestwa niebieskiego, im zaś nie dano" (Mt 13, 10). Chwilę później Mateusz powiada, powtarzając echem Psalmy 49, 4 i 78, 2: „To wszystko mówił Jezus tłumom w przypowieściach, a bez przypowieści nic im nie mówił. Tak miało się spełnić słowo Proroka: »Otworzę usta w przypowieściach, wypowiem rzeczy ukryte od założenia świata«" (Mt 13, 34-35). Nowy Testament, a zwłaszcza przypowieści Jezusa, można zdefiniować jako zdradzanie tajemnic, których już Stary Testament strzegł poprzez ich zdradzanie, tak jak w czytelnej/nieczytelnej historii o Abrahamie i Izaaku z Księgi Rodzaju ${ }^{50}$.

Biblijnego (zwłaszcza nowotestamentowego) i literackiego (zwłaszcza powieściowego) narratora łączy zatem analogiczna postawa, zgodnie z którą poznanie nie może zostać utrzymane w tajemnicy. Sekret należy odkryć, prawdę - objawić. Jeśli jednak Miller jest przekonany, że nie da się ani Biblii przekształcić w literaturę, ani odwrotnie, to nie wynika z tego postulat „niemożliwej filiacji”. Wręcz przeciwnie: związek jest uchwytny pod warunkiem uzgodnienia wspólnej episteme.

Dla Prusa - sądząc z wybranych przez niego cytatów - wiedza biblijna dotyczy przede wszystkim pragnienia i jego konsekwencji. Dlatego w Lalce nieustannie pojawia się opozycja między ,zgorszeniem” a „błogosławieństwem”; między „sidłami” a „marnością”. Pisarz tematyzuje i dookreśla te przeciwieństwa, pokazując, jaką rolę odgrywają one w egzystencjach indywidualnej i zbiorowej. Na tym polega dialog, który powieść ta prowadzi z Biblia.

Niewątpliwie, pozostaje on ukryty $\mathrm{i}$ - na powierzchni tekstu - zaledwie zasugerowany. Prus ewidentnie założył, iż jego rozpoznanie będzie dostępne tylko dla tych, którzy operują albo dyskursem teologicznym, albo własną intuicją wyniesioną z lektury Biblii. W ten sposób - fantastycznie paradoksalny - pisarz uratował autonomię powieści, a zarazem uczynił z niej kolejną przypowieść, objawiającą „rzeczy ukryte od założenia świata”.

Abstract

CEZARY ZALEWSKI

(Jagiellonian University of Cracow)

\section{"WHEAT AND CORN COCKLE." \\ BIBLICAL INTERTEXTS IN BOLESŁAW PRUS' "THE DOLL"}

The article aims at analyzing the function that Biblical quotations perform in Bolesław Prus' The Doll (Lalka). In the first part the author examines the prefigurative potential of the signalled quotations which demarcate the lot of many minor characters (e.g. the Wysocki brothers, baron and baroness Krzeszowscy). The second part discusses so called "acts of quoting" in which intertextual relations are cut down to the scenes the quotations appear (e.g. the walk in Powiśle, the events in Skierniewice). In both cases the Bible as well as the theological discourse that interprets it prove to be a functional tool for understanding a number of unclear fragments in Prus' masterpiece.

50 J. H. Mill e r, Literatura i „,Biblia”. Filiacja niemożliwa. Przeł. K. H o ff m a n n. „Przestrzenie Teorii” 2009, nr 11, s. 269-270. 